


\section{Effect of reducing dietary crude protein in hog finisher barrows and gilts on technical performance}

Patricia Pluk ${ }^{1}$, Marinus van Krimpen ${ }^{2}$

${ }^{1}$ Cargill Animal Nutrition

2 Wageningen Livestock Research

This research was conducted by Cargill Animal Nutrition and Wageningen Livestock Research, within the framework of the public private partnership "Feed4Foodure", partially funded by the Ministry of Economic Affairs (Policy Support Research; project number BO-31.03-005-001), and supported by Vereniging Diervoederonderzoek Nederland (VDN).

Wageningen Livestock Research

Wageningen, September 2018

Report 1111 


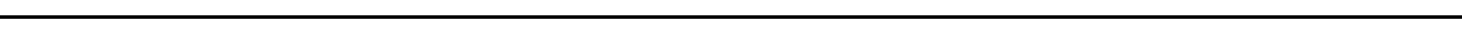


Patricia Pluk, Marinus van Krimpen, 2018; Wageningen Livestock Research, Report 1111.

This report can be downloaded for free at https://doi.org/10.18174/458060 or at www.wur.nl/livestock-research (under Wageningen Livestock Research publications).

(C) 2018 Wageningen Livestock Research

P.O. Box 338, 6700 AH Wageningen, The Netherlands, T +31 (0)317 4839 53,

E info.livestockresearch@wur.nl, www.wur.nl/livestock-research. Wageningen Livestock Research is part of Wageningen University \& Research.

All rights reserved. No part of this publication may be reproduced and/or made public, whether by print, photocopy, microfilm or any other means, without the prior permission of the publisher or author.

Wageningen Livestock Research is NEN-EN-ISO 9001:2015 certified.

All our research commissions are in line with the Terms and Conditions of the Animal Sciences Group. These are filed with the District Court of Zwolle.

Wageningen Livestock Research Report 1111

Dit rapport is gratis te downloaden op https://doi.org/10.18174/458060 of op www.wur.nl/livestock-research (onder Wageningen Livestock Research publicaties).

(C) 2018 Wageningen Livestock Research

Postbus 338, 6700 AH Wageningen, T 03174839 53, E info.livestockresearch@wur.nl, www.wur.nl/livestock-research. Wageningen Livestock Research is onderdeel van Wageningen University \& Research.

Wageningen Livestock Research aanvaardt geen aansprakelijkheid voor eventuele schade voortvloeiend uit het gebruik van de resultaten van dit onderzoek of de toepassing van de adviezen.

Alle rechten voorbehouden. Niets uit deze uitgave mag worden vermenigvuldigd en/of openbaar gemaakt worden door middel van druk, fotokopie, microfilm of op welke wijze dan ook zonder voorafgaande toestemming van de uitgever of auteur.

Wageningen Livestock Research is NEN-EN-ISO 9001:2015 gecertificeerd.

Op al onze onderzoeksopdrachten zijn de Algemene Voorwaarden van de Animal Sciences Group van toepassing. Deze zijn gedeponeerd bij de Arrondissementsrechtbank Zwolle. 


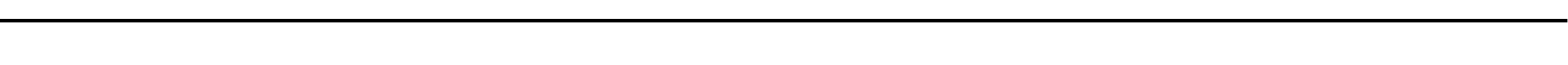




\section{Table of contents}

$\begin{array}{ll}\text { Table of contents } & 5\end{array}$

$\begin{array}{ll}\text { Summary } & 7\end{array}$

1

$\begin{array}{ll}\text { Introduction } & 9\end{array}$

2

$\begin{array}{ll}\text { Materials and Methods } & 11\end{array}$

$2.1 \quad$ Experimental design 11

2.2 Diets 12

2.3 Animals, Environment, and Sample Management 12

2.4 Analysis 12

2.5 Results and Discussion 13

2.6 Diet analyses (Appendix II) 13

2.7 Performance and broken-line analyses (Appendix III and IV) 13

2.8 Phase $1(30-55 \mathrm{~kg} \mathrm{BW}) \quad 14$

2.9 Phase $2(55-80 \mathrm{~kg} \mathrm{BW}) \quad 16$

2.10 Phase $3(80-120 \mathrm{~kg} \mathrm{BW}) \quad 17$

2.11 Carcass (Appendix IV) $\quad 20$

2.12 Carbon Footprint $\quad 21$

$3 \quad$ Conclusions $r 2$

$\begin{array}{llr}4 & \text { References } & 24\end{array}$

$\begin{array}{lll}\text { Appendix 1: } & \text { Diet formulations } & 27\end{array}$

APPENDIX II: Diet analyses $\quad 34$

APPENDIX III: Results table performance Main effects 37

APPENDIX IV: Broken-line analyses

APPENDIX V: Carcass characteristics $\quad 44$ 


\section{Summary}

The objective of this study was to determine the effect of reducing dietary crude protein (CP) levels in hog finisher barrows and gilts on animal performance. Diets were formulated to meet the requirements of the first six essential amino acids. It was hypothesised that lowest dietary CP levels without negative effects on technical performance would be close to treatments $D$ (barrows) and J ( gilts). From those CP level onwards, isoleucine (and histidine) likely became limiting factors. The most important conclusions are mentioned below.

\section{Performance}

\section{0-55 kg BW:}

- $\quad$ The response to $\mathrm{CP}$ level was different in barrows compared to gilts ( $P$ interaction<0.05). In barrows, best performance was obtained at a CP level of $14.5 \%$ whereas gilts performed best at $15.5 \% \mathrm{CP}$. These CP levels also resulted in lowest cost per $\mathrm{kg}$ gain for barrows and gilts respectively.

- Broken-line analysis indicated a minimum CP level of $14.7 \%$ and $15.1 \%$ for barrows and gilts respectively. This is in line with literature. Based on the diet composition in the current trial, soybean meal inclusion at this CP level would be approximately $12.5 \%$ and its inclusion could thus be reduced by $36 \%$.

\section{5-80 kg BW:}

No interactions were found between $C P$ level and sex ( $P$ interaction $>0.05)$.

- $\quad$ A quadratic response to CP level was observed for ADG and efficiency (both $P<0.05$ ), but not for ADFI. ADG and efficiency were highest in animals receiving $13.9 \% \mathrm{CP}$ or more.

- $\quad$ Barrows had a higher ADFI and ADG (both $P<0.001$ ), but were not less efficient compared to gilts $(\mathrm{P}=0.87)$.

Broken-line analysis indicated a minimum CP level of $14.4 \%$ for both barrows and gilts. This is partially in line with literature as levels of $11 \%$ and $11.9 \%$ have been reported to nog negatively affect ADG. However, bodyweight ranges were higher (up to $100 \mathrm{~kg}$ ). Based on the diet composition in the current trial, soybean meal inclusion at this CP level would be approximately $9.5 \%$ and its inclusion could thus be reduced by $32 \%$.

\section{0-115 kg BW:}

- No interactions occurred were found between CP level and sex ( $P$ interaction>0.05).

- Performance increased with increasing CP level and cost per kg gain decreased with increasing CP level (all $P$ linear<0.001).

- $\quad$ Barrows had a higher ADFI and ADG, but were less efficient compared to gilts (all $P<0.001$ ).

- Broken-line analysis indicated a minimum CP level of $11.7 \%$ for barrows. Based on the diet composition in the current trial, soybean meal inclusion at this CP level would be approximately $4.5 \%$ and its inclusion could thus be reduced by $55 \%$.

- Broken-line for gilts resulted in high standard error with large confidence intervals and were thus not used for interpretation.

\section{Carcass}

Differences in carcass characteristics between treatments occurred, independent of sex ( $P$ interaction>0.05). Quadratic responses were observed for final bodyweight, slaughter weight and carcass weight (all $\mathrm{P}<0.001$ ). Animals receiving the four treatments with highest $\mathrm{CP}$ levels had similar weights while the animals with lowest CP level were significantly lighter.

- Quadratic responses for loin depth and lean meat percentage were observed (both P quadratic $=0.04)$. However, expressed as a percentage of slaughter weight these responses were not observed anymore (resp. P quadratic $=0.54$ and 0.16 ).

- Barrows were significantly heavier at the end of the trial $(P<0.001)$. Expressed, as a percentage of slaughter weight, barrows had higher backfat but lower loin depth and lean meat compared to gilts (all $P<0.01$ ). 


\section{Carbon Footprint}

- Dietary Carbon Footprint (CFP) increased with decreasing dietary CP level. This was due to the increase in synthetic amino acid inclusion in the formulations and its high impact on Carbon Footprint.

- $\quad$ Animals receiving the low CP diets were more efficient converting this to gain compared to animals receiving high $\mathrm{CP}$ diets.

- The assessment on overall CFP could not be made as the tool is not able to adjust to actual performance and a three phase feeding program. 


\section{Introduction}

Providing diets with a reduced crude protein $(\mathrm{CP})$ content, that are supplemented with increased contents of free amino acids (AA) to cover the AA requirement, might be helpful in reducing the soybean meal content of Latin American origin, and thus in reducing the amount of non-EU protein in the diet. An adequate supply of AA supply is essential for maintaining performance levels of pigs that are fed low CP diets. Pig diets usually at least are optimised for the AAs lysine, methionine + cysteine, threonine, and tryptophan. In low CP diets, the requirements for valine, isoleucine, histidine and leucine should be taken into account as well (Gloaguen et al., 2014).

In Table 1, various recommended amino acid ratios, including valine, isoleucine, histidine and leucine, relative to lysine for growing pigs are compared, as provided by Guillou and Molist (In progress).

Table 1 Different amino acid patterns relative to lysine for growing pigs, as provided by Guillou and Molist (In progress).

\begin{tabular}{|c|c|c|c|c|c|c|c|c|}
\hline & $\begin{array}{c}\text { BSAS } \\
2003 \\
(\text { UK+IRL) }\end{array}$ & $\begin{array}{c}\text { Van Milgen } \\
\text { et al., } \\
2005- \\
\text { INRAporc } \\
\text { (FR) }\end{array}$ & $\begin{array}{r}\text { FEDNA } \\
(E S\end{array}$ & 006 & CVB 20 & $(\mathrm{NL}+\mathrm{B})$ & $\begin{array}{l}\text { VSP } 2013 \\
\quad(D K)\end{array}$ & $\begin{array}{l}\text { NRC } 2012 \\
\text { (USA) } \\
\text { SID }\end{array}$ \\
\hline $\begin{array}{l}\text { Amino } \\
\text { Acid }\end{array}$ & $\begin{array}{l}\text { Growing } \\
\text { pigs (10 } \\
\text { to } 120 \mathrm{~kg} \text { ) }\end{array}$ & $\begin{array}{c}\text { Growing } \\
\text { pigs }\end{array}$ & $\begin{array}{c}\text { Adaptation } \\
\text { fattening }\end{array}$ & $\begin{array}{c}20-60 \\
\mathrm{~kg}\end{array}$ & Starter & Grower & $\begin{array}{c}\text { Growers } \\
\text { and } \\
\text { Finishers }\end{array}$ & $25-50 \mathrm{~kg}$ \\
\hline LYS & 100 & 100 & 100 & 100 & 100 & 100 & 100 & 100 \\
\hline MET & 30 & 30 & 31 & $29-32$ & & & 31 & 29 \\
\hline $\mathrm{MET}+\mathrm{CYS}$ & 59 & 60 & 60 & $58-60$ & 59 & 60 & $56-61$ & 57 \\
\hline THR & 65 & 65 & 64 & $63-64$ & 57 & 59 & $63-70$ & 63 \\
\hline TRP & 19 & 18 & 19 & $17-19$ & 19 & 19 & 20 & 17 \\
\hline ILE & 58 & 60 & 59 & $58-60$ & & & 58 & 51 \\
\hline LEU & 100 & 100 & & & & & 102 & 101 \\
\hline HIS & 34 & 32 & & & & & $34-36$ & 34 \\
\hline PHE & 57 & 50 & & & & & $59-61$ & 60 \\
\hline $\mathrm{PHE}+\mathrm{TYR}$ & 100 & 95 & & & & & $116-118$ & 95 \\
\hline VAL & 70 & 70 & & & & & 70 & 66 \\
\hline ARG & & 42 & & & & & & 46 \\
\hline
\end{tabular}

As shown in Table 1, European recommendations for isoleucine are higher than in the USA (58-60 vs. $52 \%$ of lysine). Leucine recommendations are more homogeneous (100-102\% of lysine). Histidine recommendations ranged from 32 to $36 \%$ of lysine (INRA and VSP, respectively), where those for valine varied from $66 \%$ (NRC) to $70 \%$ (BSAS and Van Milgen et al., 2005).

In addition to Table 1, recent literature was reviewed to determine whether there is any evidence for changing the recommended AA patterns relative to lysine, especially in pigs fed low protein diets.

\section{Lysine level}

In 88-116 kg gilts fed low CP diets, the optimum SID Lys content to maximize ADG and optimize FCR as well as to minimize serum urea nitrogen levels were $5.7,5.8$ and $6.1 \mathrm{~g} / \mathrm{kg}$ using a linear-break point model and 6.5, 6.5 and $6.6 \mathrm{~g} / \mathrm{kg}$ using a quadratic model, respectively (Ma et al., 2015a). 
Total Sulpher Amino Acids (TSAA)

In 96 to $120 \mathrm{~kg}$ gilts fed low CP diets, the SID TSAA to lysine ratio for lowest FCR was estimated as $58 \%$, which is in accordance with the recommend ratio by the NRC (2012) (Ma et al., 2016).

\section{Threonine}

In a study of Zhang et al. (2013), in which 22-50 kg pigs were fed low CP diets supplemented with free $A A$, by using a linear-breakpoint analysis, the optimum SID Thr to Lys ratio was estimated as $68 \%, 67 \%$ and $61 \%$ for ADG, FCR and serum urea nitrogen, respectively. The ratios for optimized ADG and FCR were higher than recommended by NRC (2012). By use of linear break point analysis the optimum SID Thr to Lys ratio for $90-118 \mathrm{~kg}$ gilts fed low CP diets was estimated as $61 \%, 63 \%$ and $64 \%$ whereas the quadratic analysis estimated the optimum SID Thr to Lys ratio as $70 \%, 74 \%$ and $72 \%$ to maximize ADG, minimize FCR and serum nitrogen levels, respectively (Ma et al., 2015a). The ratios estimated with the linear break point model were slightly higher than the recommend ratio by the NRC (2012). Xie et al. (2013), who conducted an experiment in finishing pigs (72 kg BW at the start of the experiment), that were fed low CP diets, concluded that the SID Thr to Lys ratios for maximal weight gain, and minimal FCR and serum urea nitrogen were $67 \%, 71 \%$ and $64 \%$, respectively, using a linear broken-line model. These ratios are also higher than recommended by NRC (2012).

\section{Tryptophan}

Zhang et al. (2012) investigated the SID Trp to Lys ratio in 25-50 kg pigs, fed low CP diets supplemented with free AA. The SID Trp to Lys ratios that optimized weight gain, feed conversion ratio, and serum urea nitrogen were $19.7,20.0$, and $20.8 \%$ using a linear-breakpoint model, and $22.6,23.2$, and $23.6 \%$ using a curvilinear-plateau model, respectively. Taking an average of these six values, the authors concluded that the optimum SID Trp to Lys ratio is at least $22 \%$. This value is higher than currently recommended by NRC (2012). By use of linear break point analysis the appropriate SID Trp to Lys ratio for $89-121 \mathrm{~kg}$ gilts fed low CP diets was estimated as $17 \%$ using G:F as the response criteria (Ma et al., 2015b). This estimation was similar to the recommend ratio from the NRC (2012). In a study of Xie et al. (2014), conducted in 67-96 kg barrows fed low protein diets, maximized weight gain using estimates provided by the linear broken line and quadratic model were $20.3 \%$ and $25.1 \%$, respectively, while $19.7 \%$ and $22.4 \%$ for optimized FCR, and $21.4 \%$ and $24.9 \%$ for minimized serum urea nitrogen. These data suggested that the SID Trp to Lys ratio is at least $20.3 \%$ for barrows fed a low protein corn, wheat bran, and soybean meal based diet. This estimate is higher than the current NRC recommendation (NRC, 2012).

\section{Valine}

By use of a linear broken-line model, the dietary SID Val:Lys ratios required for 26 to 46,49 to 70,71 to 92 , and 94 to $119 \mathrm{~kg}$ pigs fed low CP diets were estimated to be $62 \%, 66 \%, 67 \%$, and $68 \%$, respectively (Liu et al., 2015). These estimations are in line with the recommend NRC ratios (2012).

\section{Isoleucine}

Barrows from 15 to $30 \mathrm{~kg}$, fed diets with a low crude protein content (14\%), showed to have maximal daily gain and protein deposition at a SID isoleucine to lysine ratio of 58\% (Lazzeri et al., 2017). This ratio is higher than the recommended NRC (2012) value, but in line with several European recommendations (Table 1 ).

From the available literature, it can be concluded that the in Table 1 recommended AA patterns from EU origin seem to meet the AA requirements of pigs fed low CP diets, where NRC recommendations appear to underestimate those requirements. Only for Trp, requirement in low CP diets seems to be higher than most of the values recommend in Table 1.

The current experiment was conducted to determine the effect of low CP diets, with a (partial) replacement of soybean meal by free $A A$, on technical performance, slaughter quality, animal welfare, economic performance, and the ecological footprint in hog finisher barrows and gilts. 


\section{Materials and Methods}

\subsection{Experimental design}

A total of 192 grower finisher pigs (Topigs 20 x Topigs Pietrain), blocked by body weight, were allocated in two units at the hog finisher research facilities of Cargill Animal Nutrition in Velddriel (barrows and gilts were split). The trial lasted for 14 weeks and there were three phases; 25-45 kg BW (day 0-27), 45-75 kg BW (day 27-57) and 75-115 kg BW (day 57-98). Feed was provided ad libitum during the entire trial.

Parameters of interest were ADG, ADFI, efficiency and carcass characteristics. Tail and ear scores were performed to test whether there was a negative effect of protein level on these parameters as this was recently observed by van der Meer et al. (2017). Methodology for tail and ear scores was adopted from this same author. Tails from each individual animal were scored as follows: 1 No tail damage, 2 bite marks, 3 small wound, 4 medium wound/part of the tail missing or 5 severe wound/no tail left. The score of both ears was as follows: 1 no ear damage, 2 top or bottom lesions, 3 top and bottom lesions 4 severe damage/part of ear missing or 5 ear necrosis. In addition, cost and carbon footprint per diet were calculated. Feed cost per kilogram gain could be calculated for economical assessment.

Table 1 contains the treatments per phase. Under Dutch practical conditions, CP levels of treatments $\mathrm{E}$ and $\mathrm{F}$ (and $\mathrm{K}$ and $\mathrm{L}$ ) are mostly observed. CP levels in treatments $\mathrm{A}$ (and $\mathrm{G}$ ) are slightly lower compared to what is applied until now in literature. It is expected that this treatment set will lead to a clear dose response from which optimum CP levels can be analyzed.

Table 1: Treatment table

\begin{tabular}{crccc}
\hline Treat. & \multicolumn{3}{c}{ Protein level } & Sex \\
\cline { 2 - 4 } & Phase & Phase 2 & Phase 3 & \\
\hline A & 12.5 & 10.9 & 9.3 & Gilt \\
B & 13.5 & 11.9 & 10.3 & Gilt \\
C & 14.5 & 12.9 & 11.3 & Gilt \\
D & 15.5 & 13.9 & 12.3 & Gilt \\
E & 16.5 & 14.9 & 13.3 & Gilt \\
F & 17.5 & 15.9 & 14.3 & Gilt \\
\hline G & 12.5 & 10.9 & 9.3 & Barrow \\
H & 13.5 & 11.9 & 10.3 & Barrow \\
I & 14.5 & 12.9 & 11.3 & Barrow \\
J & 15.5 & 13.9 & 12.3 & Barrow \\
K & 16.5 & 14.9 & 13.3 & Barrow \\
L & 17.5 & 15.9 & 14.3 & Barrow \\
\hline
\end{tabular}

The crude protein levels in treatment $\mathrm{E}$ and $\mathrm{K}$ are close to Dutch practical conditions, while the lowest protein levels (treatments A and G) are slightly lower compared to what is used until now in literature. 


\section{$2.2 \quad$ Diets}

Batches of raw materials were reserved at the ABZ-diervoeding production factory, Leusden, The Netherlands. Reserved batches were analysed on crude protein, crude fat, crude ash, moisture, crude fibre (NIRS) at Provimi Rotterdam Laboratory, The Netherlands.

Formulation of diets was based on the analysed nutrient content of the ingredients. In agreement with the F4F project team, amino acid ratios (Thr, Trp, Met and Met+Cys) were based on INRA recommendations (formulated on CVB SID values). For SID valine, a ratio of $67 \%$ was set as a minimum to better reflect current Dutch standard (instead of $70 \%$, as recommended by INRA). Energy levels were set at 1.10 EW. SID Lysine levels were based on actual requirement of the animals. Treatments with lowest and highest crude protein levels were produced and mixed before pelleting to obtain the other treatments. Diet formulations are included in appendix I.

\subsection{Animals, Environment, and Sample Management}

Animals (Topigs $20 \times$ Topigs Pietrain) were housed at the hog finisher facilities at GIC Velddriel. Each pen contained 4 animals, until experimental day 77. At this day one pig per pen was removed. At that age, animals were estimated to weigh approximately $100 \mathrm{~kg}$ and due to EU regulation regarding housing conditions (space allowance) of the pigs it is not allowed to have 4 animals per pen anymore. The animal that came closest to the average body weight of that specific pen was removed. Barrows and gilts were equally distributed among treatments. Temperature, humidity and ventilation were automatically controlled.

At slaughter, pigs were weighed and transported to a commercial processing plant (Vion, Boxtel, The Netherlands). Each pig received an ear tag according to pen number to allow for data retrieval by pen and carcass data collection at the packing plant. Hot carcass weights (HCW) were measured immediately after evisceration and each carcass was evaluated for backfat, loin depth, and lean percentage. Backfat depth and loin depth were measured with an optical probe inserted between $3^{\text {rd }}$ and $4^{\text {th }}$ last rib. Lean percentage was provided from the packing plant by using a proprietary equation. Percentage yield was calculated by dividing HCW by live weight obtained before transport to the packing plant.

\subsection{Analysis}

Diets were routed to the Rotterdam lab to be analysed by wet chemistry. In addition, full amino acid profiles were analysed by University of Missouri (appendix II).

\section{Statistics}

Data was analysed using Mixed Model analysis (Version 9.3, SAS Institute Inc., NC, 2007) according to the statistical model as described below. Differences between treatment means were assumed to be significant based on the probability of $\mathrm{P}<0.05$ (Student t-test).

The following contrast questions were applied:

Is there a linear response to decreasing CP level?

- Is there a quadratic response to decreasing CP level?

- Is there a linear interaction between CP level and sex?

- Is there a quadratic interaction between CP level and sex? 


$$
Y_{i j k}=\mu+B W+a_{i}+\beta_{j}+a i * \beta j+C_{k}+\varepsilon_{i j k}
$$

Where:

$$
\begin{aligned}
& \mathrm{Y}_{\mathrm{ijk}} \quad=\text { a specific trait per experimental unit. } \\
& \mu \quad=\text { overall mean } \\
& \text { BW }=\text { co-variable of body weight at start of the trial (day } 0 \text { ) } \\
& a_{i} \quad=\text { fixed effect of CP level }(i=1-6) \\
& \beta_{\mathrm{j}} \quad=\text { fixed effect of } \operatorname{sex}(\mathrm{j}=\text { barrow }- \text { gilt }) \\
& \mathrm{a}_{\mathrm{i}} * \beta_{\mathrm{j}} \quad=\text { interaction between } \mathrm{CP} \text { level and sex } \\
& \mathrm{C}_{\mathrm{k}} \quad=\text { random effect of weight block }(\mathrm{k}=1-4) \\
& \varepsilon_{\mathrm{ijk}} \quad=\text { error term }
\end{aligned}
$$

In case of quadratic responses, broken line analysis could be performed to determine minimum crude protein level. In case of an interaction between CP level and sex, broken-line analysis was performed for barrows and gilts separately.

\subsection{Results and Discussion}

\subsection{Diet analyses (Appendix II)}

Diets were analysed on total amino acid content at the University of Missouri. For lysine, the difference between analyses versus formulation ranged between minus $2 \%$ to plus $8 \%$, which is within an acceptable range taking the analysis error into account. For methionine and cysteine however, analysed values were respectively $\approx 15 \%$ and $\approx 18 \%$ lower compared to the formulation. In general, deviations seemed similar across all treatments with minor exceptions for the two treatments with lowest CP levels (slightly lower SID M+C/SID Lys in phase 2 and 3 and SID Val/SID Lys in phase 3 compared to the other treatments). However, differences are very small and the analysis error needs to be taken into account. Therefore, no inference can be made to what extend this potentially affected the observed responses.

\subsection{Performance and broken-line analyses (Appendix III and IV)}

\section{Overall (30-120 kg BW)}

General health status was high in the current trial as medication usage was low and animal performance high (>900 gram/day). During the entire period, a total of 7 animals were removed from trial because of minor health issues ranging from animals lacking growth for no obvious reason, rectal prolapse to leg injury. At day two of the trial, four animals had tail bite marks (score 2), three animals had small wounds (score 3) and one animal had a medium wound (score 4) on his tail. In addition, 17 animals received a score 2 on ear biting (top or bottom lesion). All of these animals were equally divided over the treatments with $12.5 \%, 13.5 \%, 14.5 \%$ and $15.5 \%$ CP. However, since animals were only on trial for one day it is more likely that this was left over from the nursery or the result of reallocation (hierarchy determination) rather than dietary treatment. Since tail and ear biting was virtually not observed throughout the rest of the trial, no statistical analyses was performed on these parameters.

ADG of the entire trial was $906 \mathrm{gram} /$ day (Dutch average $811 \mathrm{gram} / \mathrm{day}$ ) with an ADFI of $2.3 \mathrm{~kg} / \mathrm{day}$ on average. FCR was on average 2.55 when all treatments were included. However, animals that had received treatments with lowest $\mathrm{CP}$ levels clearly had worse efficiency. Excluding this treatment results in an average FCR of 2.51 (Dutch average 2.57). With 956 gram/day, barrows gained on average 100 
gram/day more compared to gilts $(P<0.001)$. Together with a $17 \%$ higher feed intake $(P<0.001)$, barrows were $4 \%$ less efficient compared to gilts $(P<0.001)$ in the overall trial.

\subsection{Phase $1(30-55 \mathrm{~kg} \mathrm{BW})$}

The response to CP level was different in barrows compared to gilts. Figure 1 shows that gilts reached highest gain of $910 \mathrm{gram} /$ day at $15.5 \% \mathrm{CP}$ level whereas barrows reached highest gain of 948 gram/day at a CP level of $14.5 \%$ ( $P$ interaction=0.05). In both sexes, CP levels of $12.5 \%$ and $13.5 \%$ resulted in the lowest ADG (790 and $841 \mathrm{gram} /$ day for gilts and barrows respectively). For gilts this could have been caused by the much lower feed intake. ADFI at lowest CP levels was on average 1.56 $\mathrm{kg} /$ day whereas the highest feed intakes were reached at $14.5 \%$ and $15.5 \% \mathrm{CP}$ level (on average 1.70 $\mathrm{kg} /$ day).

In addition, a significant interaction occurred on FCR $(P=0.04)$. Gilts receiving $15.5 \%$ CP clearly showed highest efficiency compared to all other treatments whereas barrows obtained highest efficiency at $14.5 \% \mathrm{CP}$ and higher. Consequently, lowest feed cost per kg gain was obtained at $15.5 \%$ $\mathrm{CP}$ level in gilts and $14.5 \% \mathrm{CP}$ level in barrows (Figure 2, P interaction=0.05).
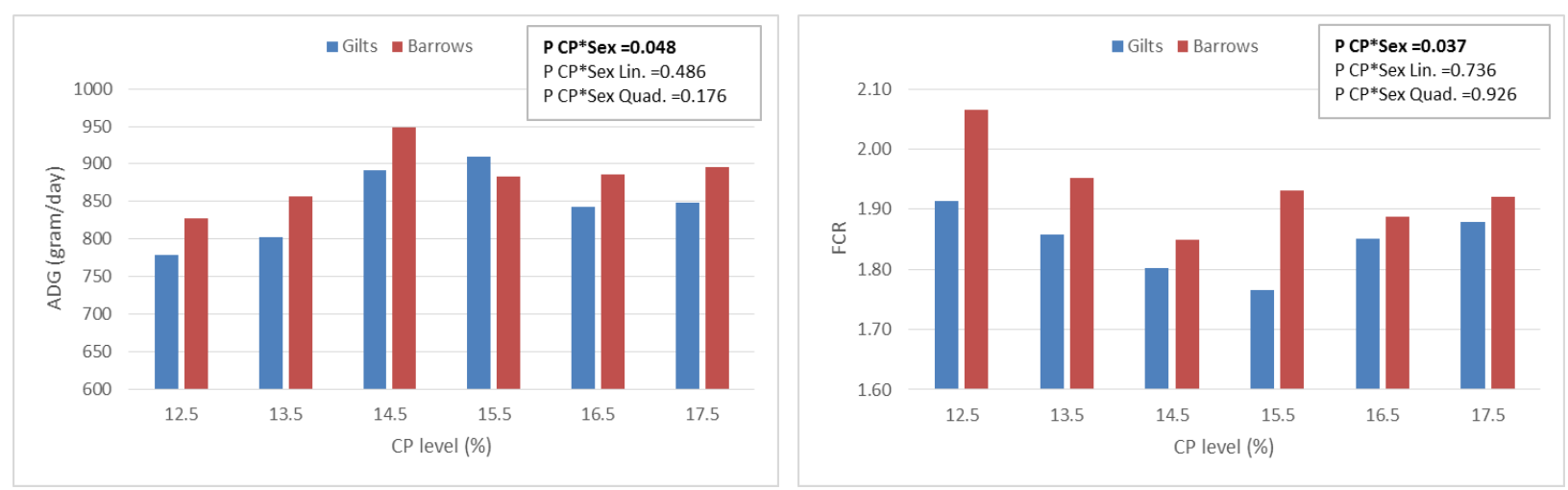

Figure 1: The effect of CP level on ADG (left) and FCR (right) in gilts and barrows from $30-55 \mathrm{~kg} B W$

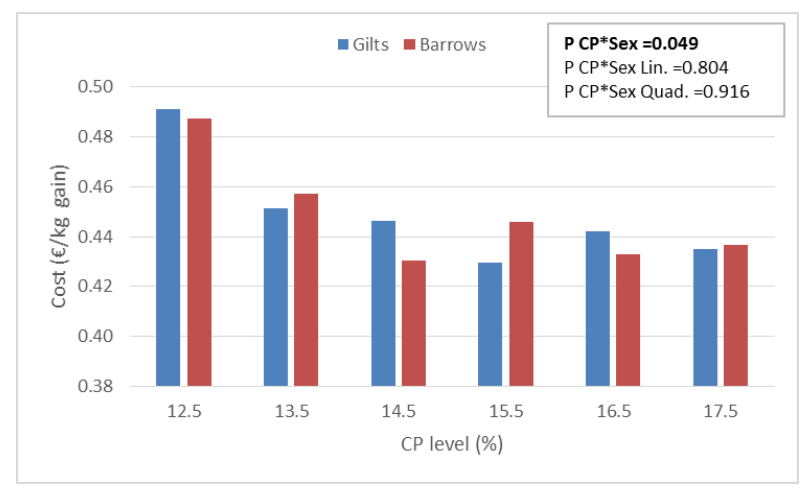

Figure 2: The effect of $C P$ level on cost per $\mathrm{kg}$ gain ( $€$ ) in gilts and barrows from $30-50 \mathrm{~kg} \mathrm{BW}$

Minimum CP level for barrows is $14.7 \%$ and gilts is $15.1 \%$

Since significant interactions between CP level and sex occurred (showing that barrows responded differently to the CP levels compared to gilts), broken-line analyses to determine minimum CP levels were performed for gilts and barrows separately (Appendix V). To achieve optimum ADG and efficiency, CP level should be at least $14.7 \%$ (Figure 3, left) and $14.6 \%$ in barrows respectively. Due to the lack of a quadratic response, broken-line analyses could not be performed to determine optimum feed intake. For gilts, minimum CP levels to obtain optimum ADG, ADFI and efficiency are 
respectively $15.6 \%$ (Figure 1 , right), $15.5 \%$ and $14.1 \%$. For mixed sex, an average minimum of $15.0 \%$ should be taken in to account.
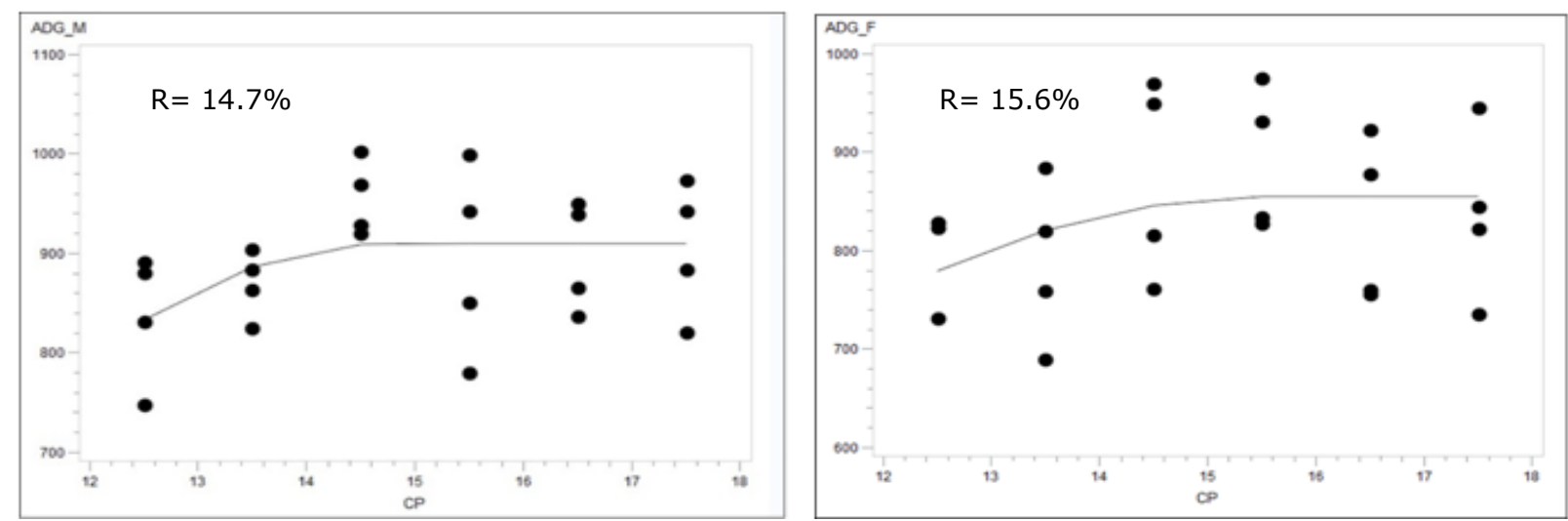

Figure 3: $\quad$ Minimum CP level for gain in barrows (left) and gilts (right) of 30-55 kg BW determined by broken line analysis.

It must be noted that these minimum $\mathrm{CP}$ levels are valid when diets are formulated on the first six essential amino acids. In the phase 1 formulations of the current trial, isoleucine levels became limiting from CP level 15.5\% and lower (assuming INRA recommendation of SID Ile/SID Lys: $60 \%$ ). For leucine and histidine this was the case at CP level $13.5 \%$ and lower (INRA: $100 \%$ and $32 \%$ respectively). Most likely, the combination of limiting isoleucine, leucine and histidine caused animals to perform worse in the treatments with $13.5 \%$ and $12.5 \% \mathrm{CP}$. Lower CP levels might be feasible when animals' requirements on these amino acids are also taken into account.

Minimum CP level determined by current trial is in line with literature

From 2000 onwards, a series of papers have been published in which the response to different CP levels was investigated (Figure 4). It must be noted that in these studies, diets have been formulated to meet animal requirements on the first six essential amino acids and if needed these were added synthetically. In three studies, CP levels were decreased to a similar extend as in the current trial and also similar body weight ranges were applied (25-55 kg BW). Figueroa et al. (2012) reported a significant $(P<0.05)$ decrease in ADG when CP level was reduced from $16.2 \%$ to $13.0 \%$ whereas Martinez-Aispuro et al. (2014) observed a negative trend when going from $14.5 \%$ to $11.5 \% \mathrm{CP}$ $(P<0.09)$. For FCR however, the latter study showed no negative response to the low level $(P>0.10)$. These studies are very much in line with the current trial in which CP levels below $14.5 \%$ also showed to have a negative effect on performance. In the study of Powell et al. (2011), 13\% CP did not negatively affect AGD ( $P>0.1)$. However, it must be noted that synthetic glycine and arginine were added to the diets which most likely mitigated the negative response to low $\mathrm{CP}$.

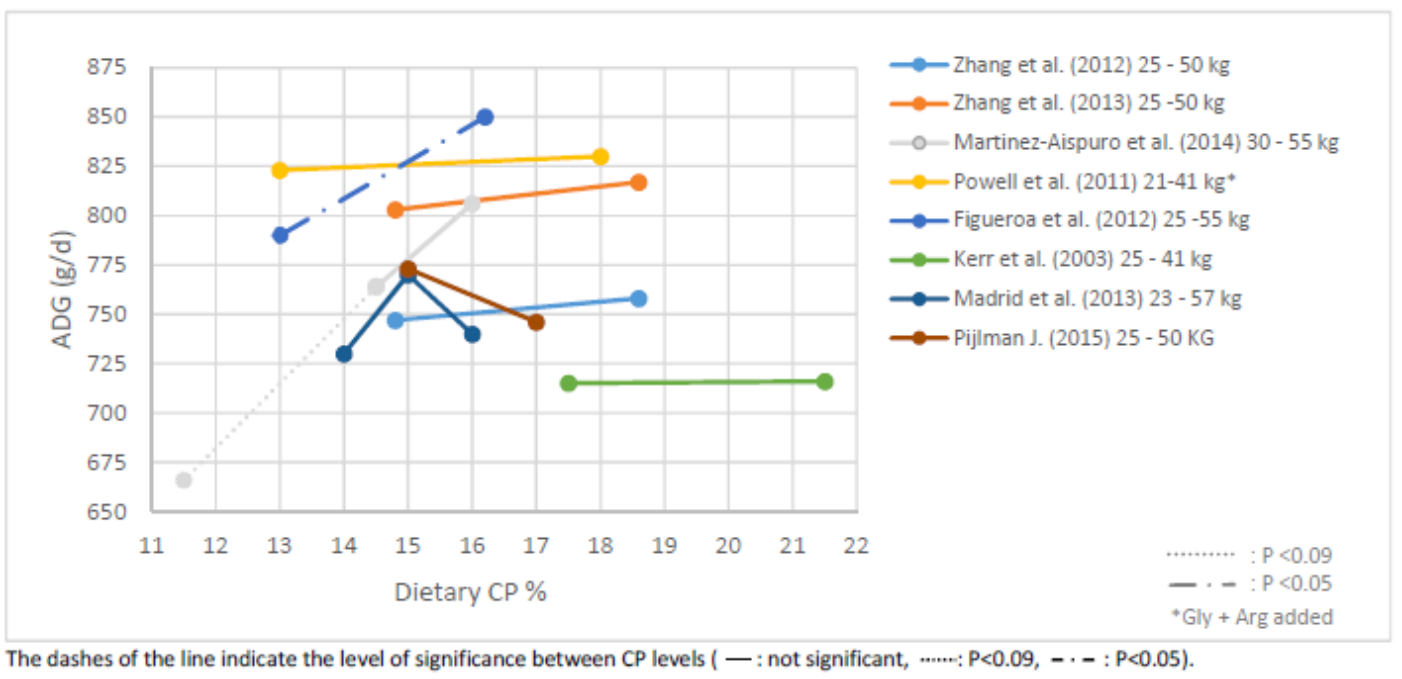

Figure 4: Effect of reducing dietary CP level on ADG in 20-60 kg BW animals as reported in literature 


\subsection{Phase 2 (55-80 kg BW)}

In 55-80 kg BW animals, no interactions occurred between CP level and sex, indicating that the response to $C P$ level was similar in barrows and gilts. A quadratic response to $C P$ level was observed for ADG and efficiency, but not for ADFI. Figure 5 shows that ADG was highest in animals receiving $13.9 \% \mathrm{CP}$ or more ( $\mathrm{P}$ quadratic $=0.003$ ). FCR was highest $(2.82)$ in animals receiving the low $C P$ level and lowest (2.49) at $13.9 \%$ (P quadratic=0.011).

$\mathrm{CP}$ levels of $13.9 \%$ and higher resulted in the lowest feed cost per $\mathrm{kg}$ gain, being on average $€ 0.54$ (P quadratic $=0.007$ ).
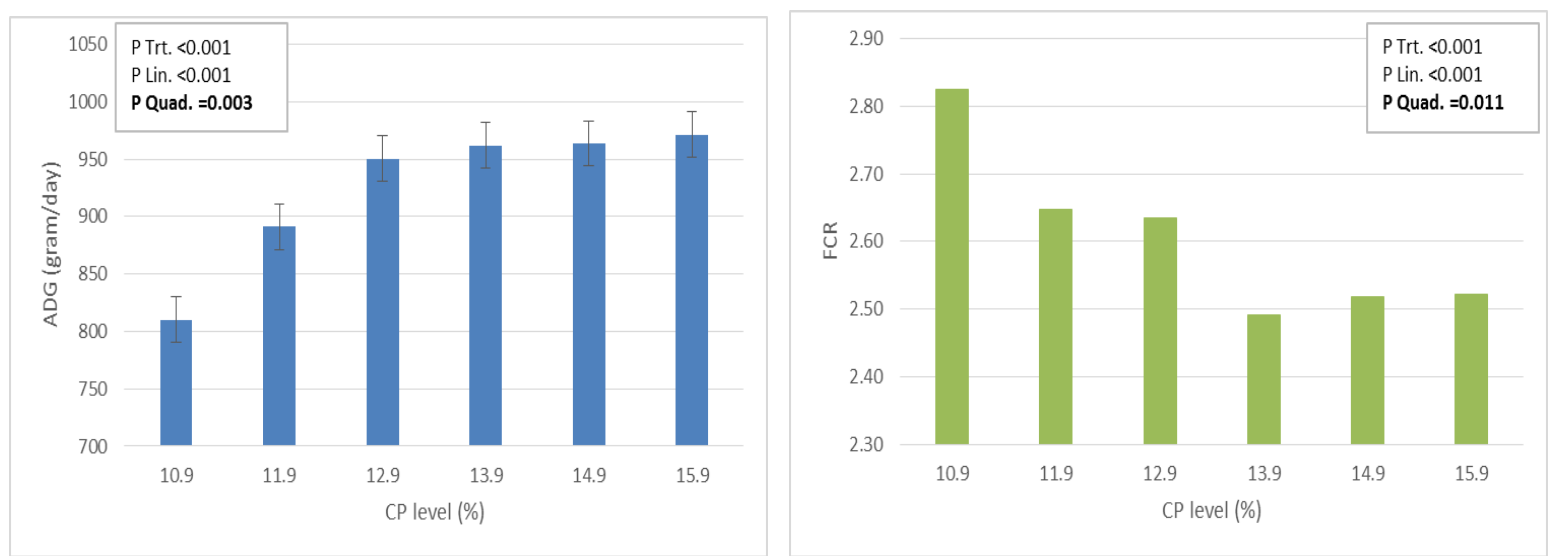

Figure 5: $\quad$ The effect of CP level on ADG (left) and FCR (right) in 55-80 kg BW animals

Note: error bars contain all sources of variation in the experiment, including that from random factors. However, only residual error variance is used for significance testing.

Barrows had an ADG of almost $1 \mathrm{~kg}$ per day, whereas gilts gained almost $17 \%$ less at $851 \mathrm{gram} /$ day $(P<0.001)$. A similar difference between barrows and gilts $(18 \%)$ was observed for ADFI $(P<0.001)$. In terms of efficiency however, both sexes were similar at an FCR of $2.6(P=0.87)$. So, barrows had a higher ADFI and ADG, but were not less efficient compared to gilts.

Since no interaction between CP level and sex occurred, broken-line analyses to determine minimum $\mathrm{CP}$ level was performed for both sexes combined. These analyses show that minimum CP level to obtain optimum ADG and efficiency should be respectively $14.0 \%$, and $14.8 \%$ (Figure 6 ). For ADFI, the minimum level is $13.4 \%$. However, the standard error of this fit is relatively high (5.1) with large confidence intervals which makes this level less reliable. On average, minimum CP level for barrows and gilts is $14.4 \%$.
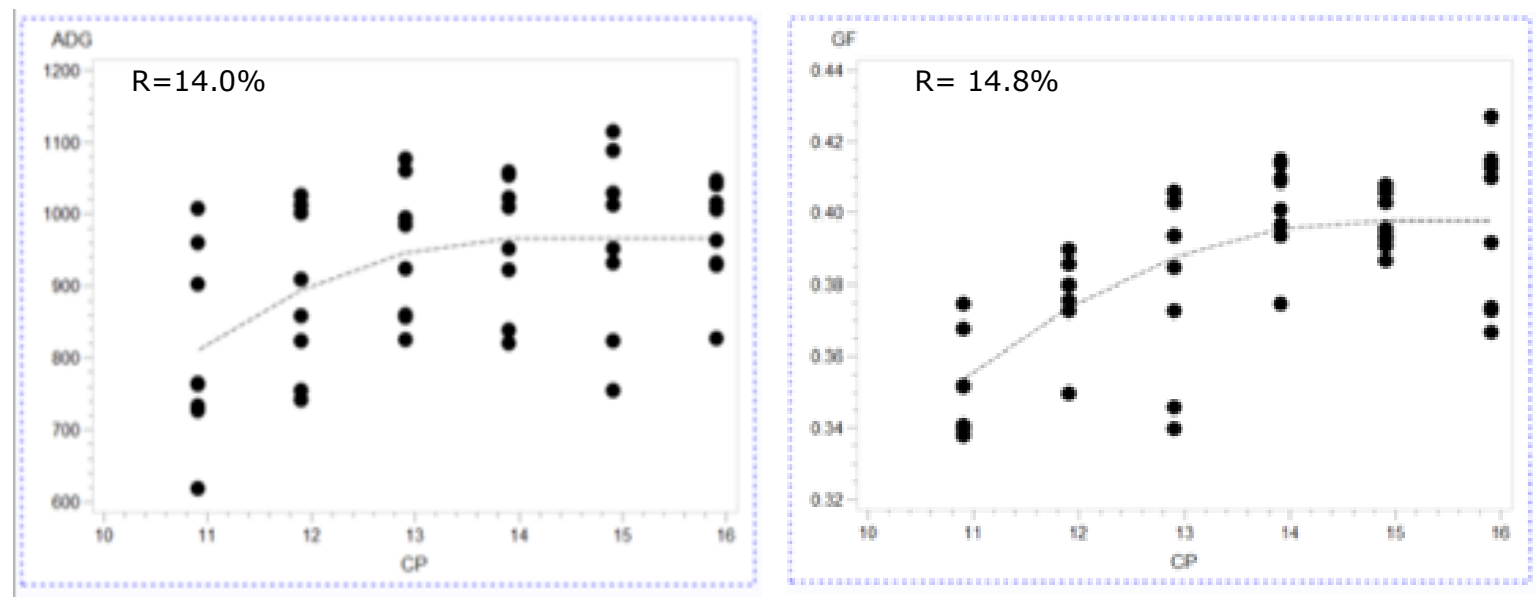

Figure 6: $\quad$ Minimum CP level for gain (left) and efficiency (right) in barrows and gilts (55-80 kg BW) determined by broken line analysis. 
Similar to the phase 1 formulations, phase 2 formulations are based on INRA recommendations for the first 6 essential amino acids (except valine which is set on $67 \%$ compared to lysine). Based these recommendations, isoleucine became limiting in diets from $13.9 \% \mathrm{CP}$ and lower whereas leucine and histidine became (close to) limiting in the treatments with $11.9 \%$ and $10.9 \%$ CP. Similar to phase 1 , ADG of animals receiving these treatments was significantly worse. For efficiency it was less evident.

The minimum $\mathrm{CP}$ level determined in the current trial is partially in line with literature. Figure 7 shows that a CP level of respectively $11.9 \%$ and $12.1 \%$ did not negatively affect ADG (both P>0.1) in studies of Martinez-Aispuro et al. (2014) and Carpenter et al. (2004). This is in contrast with findings from the current trial which clearly showed decreased ADG below a CP level of $12.9 \%$. However, it must be noted that the body weight range in which these trials were performed were higher (up to $100 \mathrm{~kg} B W$ ) compared to the current trial and thus different responses can be expected. In addition, MartinezAispuro et al. (2014) performed a trial in 45-95 kg animals and did observe a negative response when decreasing $\mathrm{CP}$ level from $14.0 \%$ to $11.0 \%(\mathrm{P}<0.09)$.

In terms of efficiency, only in studies from Martinez-Aispuro et al. (2014), Kerr et al. (2013) and Madrid et al. (2013), CP levels below 14.0\% did not have a negative effect (all $P>0.1$ ).

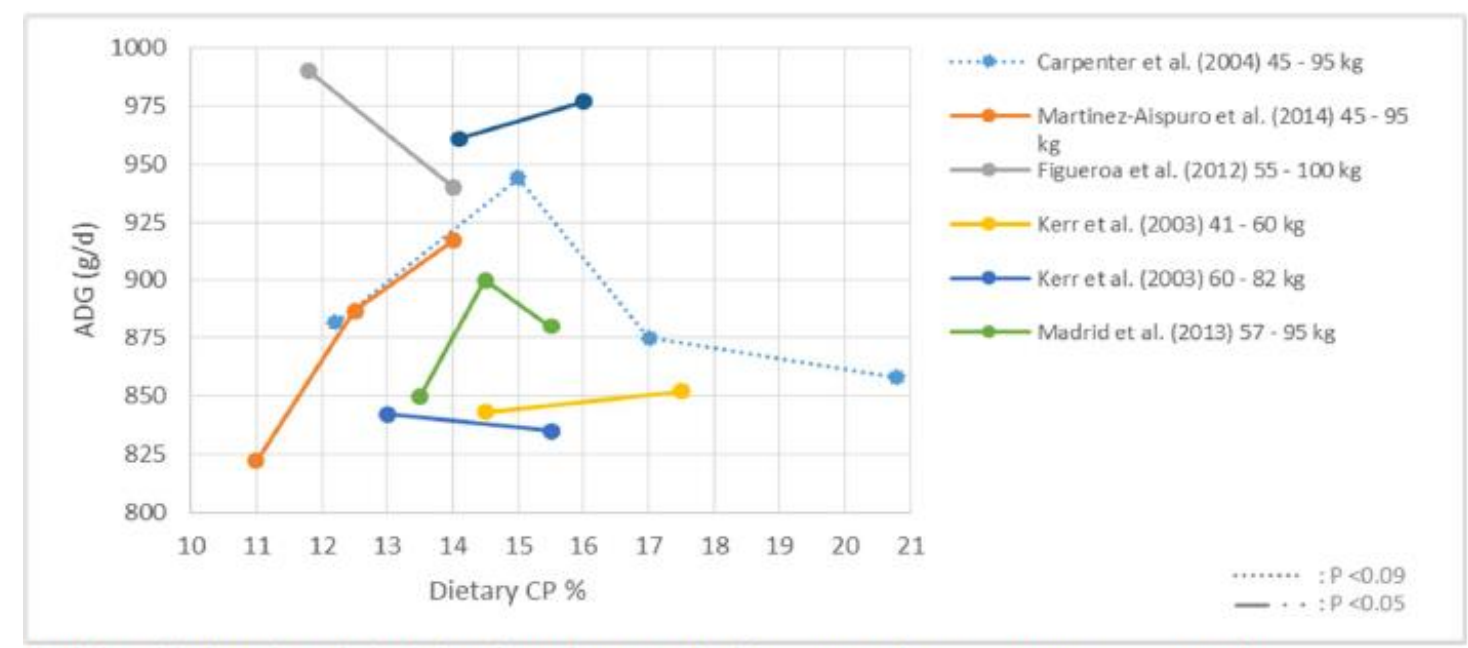

The dashes of the line indicate the level of significance between CP levels $(-:$ not significant, $\cdots \cdots \cdot \mathrm{P}<0.09,-\cdots: \mathrm{P}<0.05)$.

Figure 7: Effect of reducing dietary CP level on ADG in 40-100 kg BW animals as reported in literature

\subsection{Phase 3 (80-120 kg BW)}

A linear response to CP level was observed for all performance parameters. ADG linearly $(P<0.001)$ increased with increasing dietary CP level but remained at approximately $968 \mathrm{gram} /$ day from $13.3 \%$ CP onwards (Figure 8). A similar linear response was observed in ADFI with a difference of $14 \%$ between animals receiving the treatment with lowest and highest CP level ( $P$ linear $<0.001)$. Consequently, FCR tended to decrease ( $P$ linear $=0.095$ ) with lowest level observed at $12.3 \% \mathrm{CP}$ (2.90). For both ADG and FCR, the CP level of $9.5 \%$ stands out compared to all other treatments indicating that at this level the negative response was really evident. 


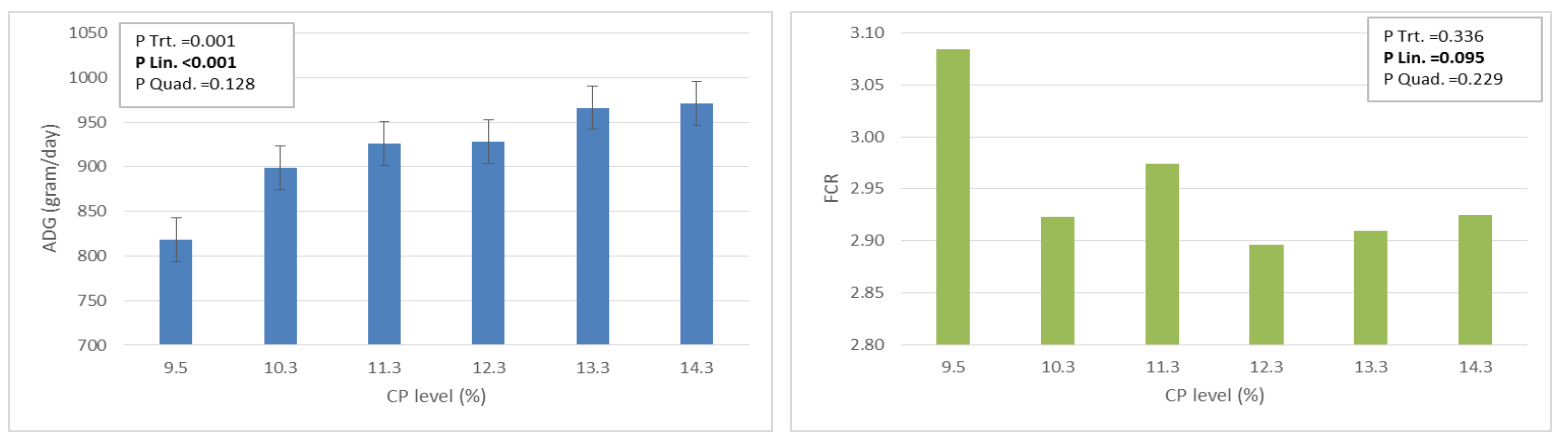

Figure 8: The effect of CP level on ADG (left) and FCR (right) in 80-120 kg BW animals

Note: error bars contain all sources of variation in the experiment, including that from random factors. However, only residual error variance is used for significance testing.

The formulation cost of dietary treatments in the current phase was relatively high due to the difficulty of reaching $9.5 \% \mathrm{CP}$. As a result, differences between treatments were also higher ( $€ 7 /$ ton) compared to the other two phases ( $€ 2 /$ ton). The linear response observed for efficiency, on top of the formulation cost, resulted in a linear $(P<0.001)$ decrease in cost/kg gain when CP level increased. As a result of the poor performance in animals receiving the diets with lowest CP level throughout the entire trial, final bodyweight was approximately $10 \%$ lower in this treatment $(110 \mathrm{~kg})$ compared to all other treatments (average $121 \mathrm{~kg}$ ). In addition, at the end of the trial (day 77 and day 98) the standard errors of the mean for bodyweight in animals receiving lowest CP levels were approximately $7 \%$ higher compared to all other treatments indicating that more variation within this treatment group started to occur.

Compared to gilts, barrows had a $12 \%$ higher ADG and $22 \%$ higher ADFI (both $\mathrm{P}<0.001$ ). As a result, gilts were $8 \%$ more efficient $(P<0.001)$ with a FCR of 2.85 .

Since no interaction between CP level and sex occurred, broken-line analyses to determine minimum CP level should have been performed for both sexes combined. However, broken-lines could not be fitted well since responses were linear and not quadratic. Therefore, sexes were separated and conclusions were drawn on broken line with good fit with low standard error and small confidence intervals. This was only the case for ADG and ADFI in barrows. Models showed that the minimum CP level should be $11.1 \%$ and $12.3 \%$ respectively (Figure 9 ). So, on average, minimum recommended CP level for barrows is $11.7 \%$
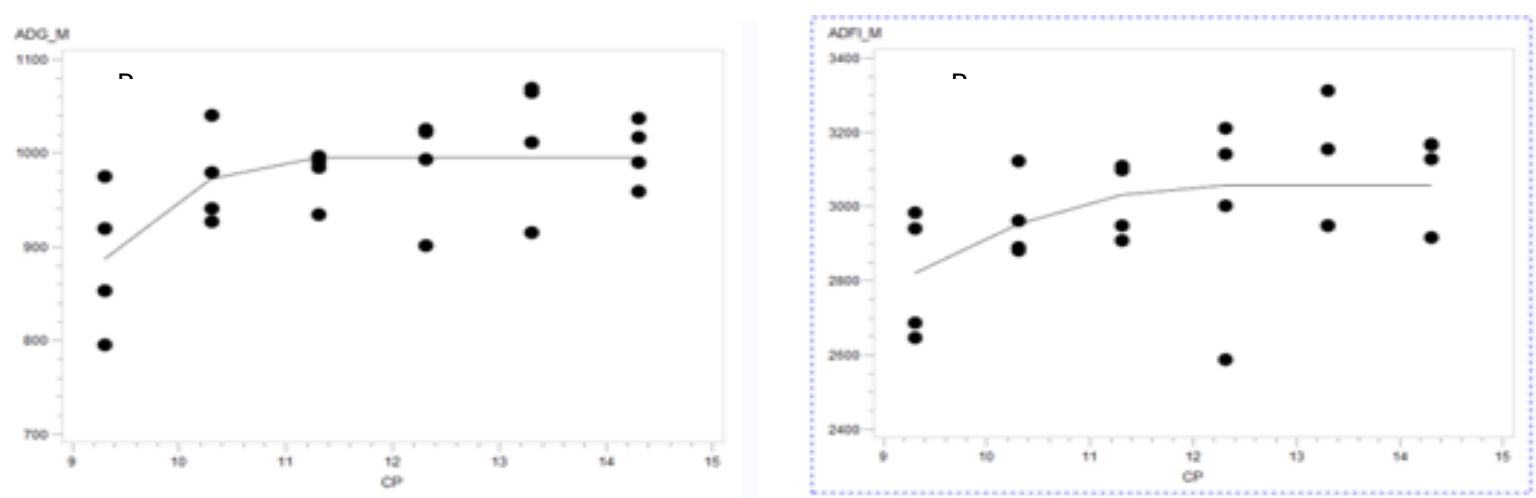

Figure 9: Minimum CP level for gain (left) and feed intake (right) in barrows (80-120 kg BW) determined by broken line analysis. 
The minimum CP level determined by current trial not completely in line with literature. From authors included in Figure 10, Ma et al. (2015), Kerr et al. (2003) and Pijlman et al. (2015) used animals that were in terms of bodyweight most close to phase 3 of the current trial. In these trials, dietary CP levels were reduced to $10.0 \%, 11.0 \%$ and $13.0 \%$ respectively without negatively affecting ADG and efficiency (all $\mathrm{P}>0.1$ ). However, data is limited and only two trials represent animals with relatively high performance (Ma et al. 2015, and Pijlman et al. 2015) similar to the current trial.

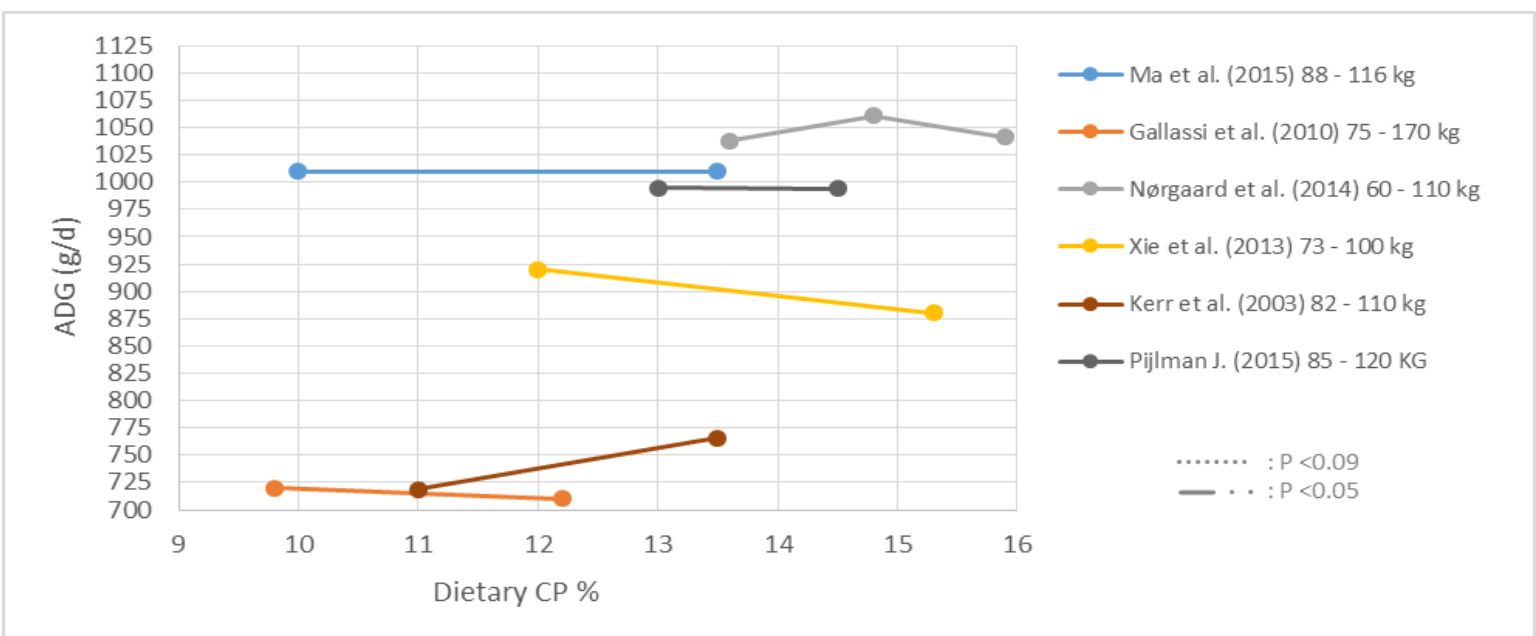

Figure 10: Effect of reducing dietary CP level on ADG in 60-170 kg BW animals as reported in literature

The current study has been performed to determine the optimum crude protein levels in finishers and, as a consequence, to what extend dietary soybean meal can be decreased. From the current trial it can be concluded that a relative reduction up to $36 \%, 32 \%$ and $55 \%$ can be achieved in $30-55 \mathrm{~kg} \mathrm{BW}$, 55-80 kg BW and 80-120 kg BW animals.

Table 2: Soybean meal (SBM) reduction per phase

\begin{tabular}{ccccc}
\hline $\begin{array}{c}\text { Phase } \\
\text { control diet }(F) \\
(\%)\end{array}$ & $\begin{array}{c}\text { SBM level at } \\
\text { optimum } \\
\text { performance } \\
(\%)\end{array}$ & $\begin{array}{c}\text { SBM saving } \\
\text { Absolute } \\
\text { (Column } 2-\text { column }\end{array}$ & $\begin{array}{c}\text { SBM saving - } \\
\text { Relative }\end{array}$ \\
(Column $4 /$ column 2 \\
$* 100)$ \\
$\mathbf{1}$
\end{tabular}




\subsection{Carcass (Appendix IV)}

Independent of sex, differences in carcass characteristics between treatments were observed. Final bodyweight ranged from $110 \mathrm{~kg}$ until $123 \mathrm{~kg}$ from the treatment with lowest $\mathrm{CP}$ to the treatment with highest CP level. Animals receiving the four treatments with highest CP levels had similar final body weights leading to a quadratic response $(P<0.001)$. Similar responses were observed for slaughter weight and carcass weight (both $\mathrm{P}$ quadratic $<0.001$ ).

Backfat was on average $15.7 \mathrm{~mm}$ with lowest level at $14.67 \mathrm{~mm}$ in treatment $D+\mathrm{J}(P$ quadratic $=0.042$. Loin depth averaged $68.75 \mathrm{~mm}$ and increased with increasing $\mathrm{CP}$ level but remained similar in the four treatments with highest $C P$ level ( $P$ quadratic $=0.043$ ). Consequently, lean meat percentage was highest in animals that received treatment $\mathrm{D}+\mathrm{J}$ at $58.71 \%(P$ quadratic $=0.035)$.

Expressing backfat, loin depth and lean meat as a percentage of slaughter weight is a method to correct for the differences in slaughter weight. Hereby it is possible to determine whether differences between treatments are caused by differences in slaughter weight or due to the actual treatment. In the current trial, the conclusion for backfat remained the same using this method but the response was less pronounced (Figure 11). For loin depth however, no differences between treatments existed anymore when expressed as a percentage of slaughter weight $(P=0.845)$. This indicates that the responses observed in absolute loin depth were caused by the differences in slaughter weight.
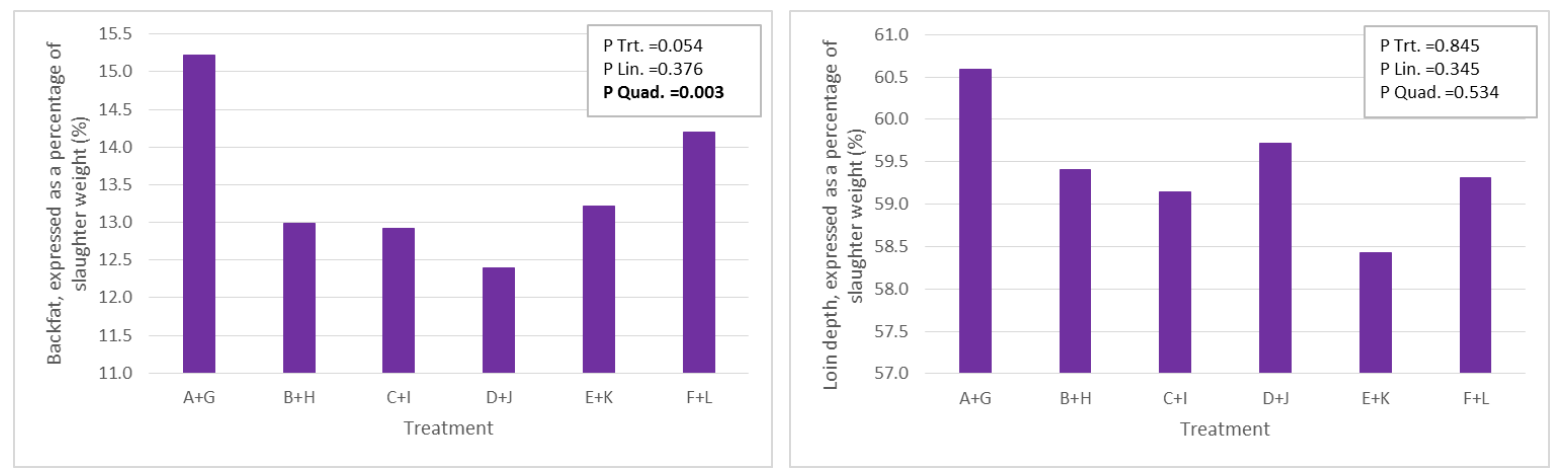

Figure 11: Backfat (left) and loin depth (right), expressed as a percentage of slaughter weight

In addition, lean meat percentage linearly decreased $(P<0.001)$ when dietary $C P$ level increased (Figure 12).

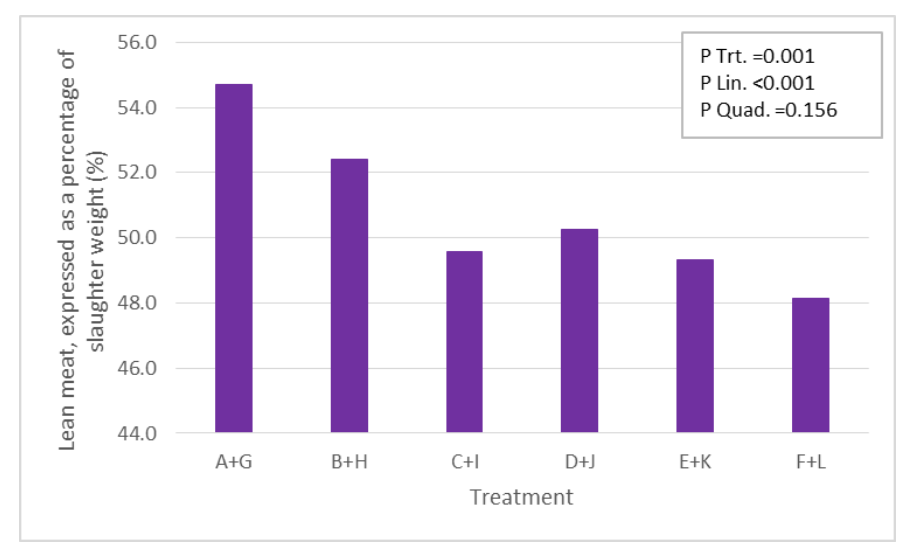

Figure 12: Lean meat, expressed as a percentage of slaughter weight

As a result of the big difference in final bodyweight between barrows and gilts, all carcass characteristics were different between the sexes as well. Expressed as a percentage of slaughter weight, backfat was still higher whereas loin depth and lean meat were lower in barrows compared to gilts (all $\mathrm{P}<0.01$ ). However, differences became less evident compared to the absolute values. 


\subsection{Carbon Footprint}

Carbon Footprint (CFP) is the total set of greenhouse gas emissions $\left(\mathrm{CO}_{2}, \mathrm{CH}_{4}\right.$ and $\left.\mathrm{N}_{2} \mathrm{O}\right)$, expressed as $\mathrm{CO}_{2}$ equivalents. In animal feed production, CFP of a diet can be calculated as each ingredient has its own CFP value. Figure 13 represents the CFP of diets A and F of each phase in the current trial. Unlike hypothesized, CFP levels of low CP diets were on average $90 \mathrm{CO}_{2}$ equivalents higher compared to the high CP diets. It was expected that decreasing soybean meal would positively affect the CFP in low CP diets. However, synthetic amino acids have extremely high CFP values (on average 13 times higher compared to soybean meal) and their relatively high inclusion in the low CP diets result in high CFP in these diets.

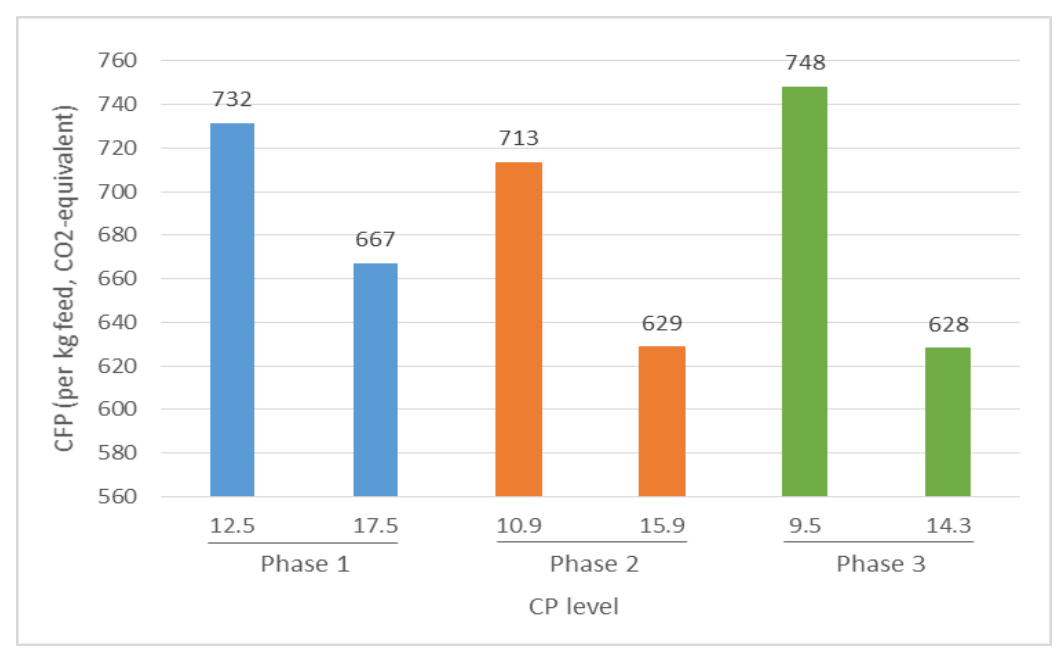

Figure 13: Carbon Footprint of treatments $A$ and $F$ per phase 


\section{Conclusions}

The most important conclusions are mentioned below.

\section{Performance}

30-55 kg BW:

- $\quad$ The response to CP level was different in barrows compared to gilts ( $P$ interaction $<0.05)$. In barrows, best performance was obtained at a CP level of $14.5 \%$ whereas gilts performed best at $15.5 \% \mathrm{CP}$. These CP levels also resulted in lowest cost per $\mathrm{kg}$ gain for barrows and gilts respectively.

- $\quad$ Broken-line analysis indicated a minimum CP level of $14.7 \%$ and $15.1 \%$ for barrows and gilts respectively. This is in line with literature. Based on the diet composition in the current trial, soybean meal inclusion at this CP level would be approximately $12.5 \%$ and its inclusion could thus be reduced by $36 \%$.

\section{5-80 kg BW:}

No interactions were found between $C P$ level and sex ( $P$ interaction $>0.05$ ).

- $\quad$ A quadratic response to CP level was observed for ADG and efficiency (both $P<0.05$ ), but not for ADFI. ADG and efficiency were highest in animals receiving $13.9 \% \mathrm{CP}$ or more.

- $\quad$ Barrows had a higher ADFI and ADG (both $P<0.001$ ), but were not less efficient compared to gilts $(P=0.87)$.

Broken-line analysis indicated a minimum CP level of $14.4 \%$ for both barrows and gilts. This is partially in line with literature as levels of $11 \%$ and $11.9 \%$ have been reported to nog negatively affect ADG. However, bodyweight ranges were higher (up to $100 \mathrm{~kg}$ ). Based on the diet composition in the current trial, soybean meal inclusion at this CP level would be approximately $9.5 \%$ and its inclusion could thus be reduced by $32 \%$.

\section{0-115 kg BW:}

- $\quad$ No interactions occurred were found between CP level and sex ( $P$ interaction $>0.05$ ).

- $\quad$ Performance increased with increasing $C P$ level and cost per $\mathrm{kg}$ gain decreased with increasing $C P$ level (all P linear<0.001).

- $\quad$ Barrows had a higher ADFI and ADG, but were less efficient compared to gilts $($ all $P<0.001)$.

- Broken-line analysis indicated a minimum CP level of $11.7 \%$ for barrows. Based on the diet composition in the current trial, soybean meal inclusion at this CP level would be approximately $4.5 \%$ and its inclusion could thus be reduced by $55 \%$.

- Broken-line for gilts resulted in high standard error with large confidence intervals and were thus not used for interpretation.

\section{Carcass}

Differences in carcass characteristics between treatments occurred, independent of sex ( $P$ interaction $>0.05$ ). Quadratic responses were observed for final bodyweight, slaughter weight and carcass weight (all $\mathrm{P}<0.001$ ). Animals receiving the four treatments with highest $\mathrm{CP}$ levels had similar weights while the animals with lowest CP level were significantly lighter.

- Quadratic responses for loin depth and lean meat percentage were observed (both P quadratic $=0.04)$. However, expressed as a percentage of slaughter weight these responses were not observed anymore (resp. P quadratic $=0.54$ and 0.16 ).

- Barrows were significantly heavier at the end of the trial $(P<0.001)$. Expressed, as a percentage of slaughter weight, barrows had higher backfat but lower loin depth and lean meat compared to gilts (all $P<0.01$ ). 


\section{Carbon Footprint}

- Dietary Carbon Footprint (CFP) increased with decreasing dietary CP level. This was due to the increase in synthetic amino acid inclusion in the formulations and its high impact on Carbon Footprint.

- $\quad$ Animals receiving the low CP diets were more efficient converting this to gain compared to animals receiving high $\mathrm{CP}$ diets.

- The assessment on overall CFP could not be made as the tool is not able to adjust to actual performance and a three phase feeding program. 


\section{$4 \quad$ References}

Carpenter, D.A., O'Mara, F.P. and O'Doherty, J.V. 2004. The effect of dietary crude protein concentration on growth performance, carcass composition and nitrogen excretion in entire grower-finisher pigs. Irish Journal of Agricultural and Food Research, 43: 227 - 236.

Figueroa, J.L., Estrada, J., Zamora, Z., Cordero, J.L., Sanchez-Torres, M.T., Nieto, R. and Copado, J.M.F. 2012. Digestible lysine levels in low-protein diets supplemented with synthetic amino acids for nursery, growing and finishing barrows. Irish Journal of Agricultural and Food Research 51: $33-44$.

Gallasi, G., Colombini, S., Malagutti, L., Crovetto, G.M. and Rapetti, L. 2010. Effects of high fibre and low protein diets on performance, digestibility, nitrogen excretion and ammonia emission in the heavy pig. Animal Feed Science and Technology, 161: $140-148$.

Gijsberts K. and Doppenberg J. Lineaire programmeringen rundvee-, varkens- en pluimveevoeders. Schothorst Feed Research. 27 October 2016. Nr. 10: p21-24.

Gloaguen, M., N. Le Floc'h, E. Corrent, Y. Primot, and J. van Milgen. 2014. The use of free amino acids allows formulating very low crude protein diets for piglets. J. Anim. Sci. 92(2):637-644.

Guillou, D., and F. Molist. In progress. Literature review: Reduction of crude protein in growing pigs and lactating sows diets. Report Schothorst Feed Research (Project VA15-04).

Kerr, B.J., Southern, L.L., Bidner, T.D., Friesen, K.G. and Easters, R.A. 2003. Influence of dietary protein level, amino acid supplementation, and dietary energy levels on growing-finishing pig performance and carcass composition. Journal of Animal Science, 81: 3075 - 3087.

Lazzeri, D. B., L. D. Castilha, P. B. Costa, R. V. Nunes, M. S. D. Pozza, and P. C. Pozza. 2017. Standardized ileal digestible (sid) isoleucine requirement of barrows (15-to $30-\mathrm{kg}$ ) fed low crude protein diets. Semin.-Cienc. Agrar. 38(5):3283-3293.

Liu, X. T., W. F. Ma, X. F. Zeng, C. Y. Xie, P. A. Thacker, J. K. Htoo, and S. Y. Qiao. 2015. Estimation of the standardized ileal digestible valine to lysine ratio required for 25-to 120-kilogram pigs fed low crude protein diets supplemented with crystalline amino acids. J. Anim. Sci. 93(10):47614773.

Ma, W., J. Zhu, X. Zeng, X. Liu, P. Thacker, and S. Qiao. 2016. Estimation of the optimum standardized ileal digestible total sulfur amino acid to lysine ratio in late finishing gilts fed low protein diets supplemented with crystalline amino acids. Anim. Sci. J. 87(1):76-83.

Ma, W. F., X. F. Zeng, X. T. Liu, C. Y. Xie, G. J. Zhang, S. H. Zhang, and S. Y. Qiao. 2015a. Estimation of the standardized ileal digestible lysine requirement and the ideal ratio of threonine to lysine for late finishing gilts fed low crude protein diets supplemented with crystalline amino acids. Anim. Feed Sci. Technol. 201:46-56.

Ma, W. F., S. H. Zhang, X. F. Zeng, X. T. Liu, C. Y. Xie, G. J. Zhang, and S. Y. Qiao. 2015b. The appropriate standardized ileal digestible tryptophan to lysine ratio improves pig performance and regulates hormones and muscular amino acid transporters in late finishing gilts fed lowprotein diets. J. Anim. Sci. 93(3):1052-1060.

Madrid, J., Martínez, S., López, C., Orengo, J., López, M.J. and Hernández, F. Effects of low protein diets on growth performance, carcass traits and ammonia emission of barrows and gilts. 2013. Animal Production Science, 53: 146 - 153. 
Martínez-Aispuro, M., Figueroa-Velasco, J.L., Zamora-Zamora, V., Cordero-Mora, J.L., Narciso-Gaytán, C., Sánchez-Torrez, M.T., Carillo-Domínguez, S. and Castillo-Domínguez, R.M. 2014. Effect of CLA supplementation on low-protein diets on the growth performance, carcass characteristics, plasma urea nitrogen concentration, and fatty acid profile in the meat of pigs. Brazilian Archives of Biology and Technology, 57 (5): 742 - 754.

Meer van der Y., Gerrits W.J.J., Jansman A.J.M., Kemp B. and Bolhuis J.E. 2017. A link between damaging behaviour in pigs, sanitary conditions, and dietary protein and amino acid supply. PLoS ONE 12(5): e0174688.

Nørgaard, J.V., Hansen, M.J., Soumeh, E.A., Adamsen, A.P.S. and Poulsen, H.D. 2014. Effect of protein level on performance, nitrogen utilization and carcass composition in finisher pigs. Acta Agriculturae Scand Section A, 64 (2): 123 - 129.

Pijlman, J. Effect of low crude protein diets on performance and carcass characteristics of growerfinisher pigs. 2015. Schothorst Feed Research. Presentation at the 21e Orffa Benelux Symposium. 28-5-15, Fletcher hotel Trivium, Etten-Leur, The Netherlands.

Powell S., Bidner, T.D., Payne, R.L. and Southern, L.L. 2011. Growth performance of 20- to 50kilogram pigs fed low-crude-protein diets supplemented with histidine, cystine, glycine, glutamic acid, or arginine. Journal of Animal Science, 89: 3643 - 3650.

Xie, C., S. Zhang, G. Zhang, F. Zhang, L. Chu, and S. Qiao. 2013. Estimation of the optimal ratio of standardized ileal digestible threonine to lysine for finishing barrows fed low crude protein diets. Asian-Australas. J. Anim. Sci. 26(8):1172-1180.

Xie, C. Y., G. J. Zhang, F. R. Zhang, S. H. Zhang, X. F. Zeng, P. A. Thacker, and S. Y. Qiao. 2014. Estimation of the optimal ratio of standardized ileal digestible tryptophan to lysine for finishing barrows fed low protein diets supplemented with crystalline amino acids. Czech J. Anim. Sci. 59(1):26-34.

Zhang, G. J., Q. L. Song, C. Y. Xie, L. C. Chu, P. A. Thacker, J. K. Htoo, and S. Y. Qiao. 2012. Estimation of the ideal standardized ileal digestible tryptophan to lysine ratio for growing pigs fed low crude protein diets supplemented with crystalline amino acids. Livest. Sci. 149(3):260266.

Zhang, G. J., C. Y. Xie, P. A. Thacker, J. K. Htoo, and S. Y. Qiao. 2013. Estimation of the ideal ratio of standardized ileal digestible threonine to lysine for growing pigs (22-50 kg) fed low crude protein diets supplemented with crystalline amino acids. Anim. Feed Sci. Technol. 180(1-4):8391. 


\section{Appendix 1: Diet formulations}

Note: price formulation ( $€ /$ ton) based on raw material prices as stated in Lineaire programmeringen rundvee-, varkens- en pluimveevoeders (Gijsberts K. and Doppenberg J., 2016). No margins added.

\section{Phase 1}

Treatment

Bestmix

code

Priceformulation

(C/ton)
$\begin{array}{lllll}A+G & B+H & C+I & D+J\end{array}$

$101 / 570.101$

235.91
234.208

\section{Ingredients}

Vleesvark. 0.75/0.5\%

Barley

Corn

Soybean meal HP

Wheat middlings

Salt

Limestone

L-Valine

L-Threonine

L-Tryptophan

Monocalciumphosphate

Sodium Bicarbonate

$24.1 \%$

Potassium Bicarbonate

Fats/oils, Palm oil

L-Lysine $\mathrm{HCL}$

DL-Methionine

\section{Nutrients}

Dry matter
Moisture
Crude protein
Crude fat
Ash
Starch (Ewers)
Calcium
Phosphorous P
Magnesium
Sodium
Potassium
Chloride
EW (energy value pigs)
SID Lysine (pigs)
SID Leucine (pigs)
SID Arginine (pigs)
SID Histidine (pigs)
SID Phenylalanine (pigs)

$\begin{array}{rrrrrr}0.750 & 0.750 & 0.750 & 0.750 & 0.750 & 0.750 \\ 37.000 & 36.766 & 36.532 & 36.297 & 36.063 & 35.829 \\ 43.936 & 42.149 & 40.362 & 38.574 & 36.787 & 35.000 \\ 4.049 & 7.132 & 10.215 & 13.298 & 16.381 & 19.464 \\ 9.000 & 8.170 & 7.341 & 6.511 & 5.682 & 4.852 \\ 0.215 & 0.262 & 0.309 & 0.356 & 0.403 & 0.450 \\ 1.197 & 1.184 & 1.171 & 1.158 & 1.145 & 1.132 \\ 0.176 & 0.141 & 0.106 & 0.070 & 0.035 & 0.000 \\ 0.292 & 0.249 & 0.206 & 0.164 & 0.121 & 0.078 \\ 0.072 & 0.058 & 0.043 & 0.029 & 0.014 & 0.000 \\ 0.737 & 0.714 & 0.690 & 0.667 & 0.643 & 0.620 \\ 0.357 & 0.286 & 0.214 & 0.143 & 0.071 & 0.000 \\ 0.456 & 0.365 & 0.274 & 0.182 & 0.091 & 0.000 \\ 0.815 & 0.951 & 1.087 & 1.224 & 1.360 & 1.496 \\ 0.745 & 0.649 & 0.553 & 0.457 & 0.361 & 0.265 \\ 0.203 & 0.175 & 0.147 & 0.120 & 0.092 & 0.064\end{array}$

$\%$

$\%$

$\%$

$\%$ 10.989 12.500

3.454

4.685

48.377

0.613

0.519

0.137

0.180

0.670

0.334

CVB

1.100

0.930

0.841

0.553

0.252

0.469
232.506

230.804

\section{1/570.105}

$\begin{array}{rrrrr}88.897 & 88.783 & 88.668 & 88.554 & 88.440 \\ 11.103 & 11.217 & 11.332 & 11.446 & 11.560 \\ 13.500 & 14.500 & 15.500 & 16.500 & 17.500 \\ 3.508 & 3.562 & 3.615 & 3.669 & 3.723 \\ 4.698 & 4.712 & 4.725 & 4.739 & 4.752 \\ 47.087 & 45.798 & 44.508 & 43.219 & 41.929 \\ 0.613 & 0.613 & 0.613 & 0.613 & 0.613 \\ 0.520 & 0.522 & 0.523 & 0.525 & 0.526 \\ 0.143 & 0.150 & 0.156 & 0.163 & 0.169 \\ 0.180 & 0.180 & 0.180 & 0.180 & 0.180 \\ 0.684 & 0.698 & 0.712 & 0.726 & 0.740 \\ 0.341 & 0.348 & 0.356 & 0.363 & 0.370 \\ 1.100 & 1.100 & 1.100 & 1.100 & 1.100 \\ 0.930 & 0.930 & 0.930 & 0.930 & 0.930 \\ 0.917 & 0.993 & 1.070 & 1.146 & 1.222 \\ 0.643 & 0.733 & 0.823 & 0.913 & 1.003 \\ 0.281 & 0.310 & 0.339 & 0.368 & 0.397 \\ 0.526 & 0.584 & 0.641 & 0.699 & 0.756\end{array}$

$\mathbf{F}+\mathbf{L}$ 


\begin{tabular}{|c|c|c|c|c|c|c|c|c|}
\hline SID Tyrosine (pigs) & $\%$ & CVB & 0.325 & 0.365 & 0.406 & 0.446 & 0.487 & 0.527 \\
\hline $\begin{array}{l}\text { SID Threo./SID Lys. } \\
\text { (pigs) }\end{array}$ & - & CVB & 0.650 & 0.650 & 0.650 & 0.650 & 0.650 & 0.650 \\
\hline $\begin{array}{l}\text { SID Trypt./SID Lys. } \\
\text { (pigs) }\end{array}$ & - & CVB & 0.180 & 0.180 & 0.181 & 0.181 & 0.182 & 0.182 \\
\hline SID Val./SID Lys. (pigs) & - & CVB & 0.670 & 0.688 & 0.706 & 0.723 & 0.741 & 0.759 \\
\hline $\begin{array}{l}\text { SID Isoleu./SID Lys. } \\
\text { (pigs) }\end{array}$ & - & CVB & 0.369 & 0.425 & 0.482 & 0.538 & 0.595 & 0.651 \\
\hline $\begin{array}{l}\text { SID Meth./SID Lys. } \\
\text { (pigs) }\end{array}$ & - & CVB & 0.399 & 0.384 & 0.370 & 0.355 & 0.341 & 0.326 \\
\hline $\begin{array}{l}\text { SID M+Cyst./SID Lys. } \\
\text { (pigs) }\end{array}$ & - & CVB & 0.600 & 0.600 & 0.600 & 0.600 & 0.600 & 0.600 \\
\hline SID Leu/SID Lys. (pigs) & & CVB & 0.904 & 0.986 & 1.068 & 1.150 & 1.232 & 1.314 \\
\hline SID His/SID Lys. (pigs) & & CVB & 0.271 & 0.302 & 0.333 & 0.365 & 0.396 & 0.427 \\
\hline SID Arg/SID Lys. (pigs) & & CVB & 0.595 & 0.691 & 0.788 & 0.885 & 0.982 & 1.078 \\
\hline SID Phe/SID Lys. (pigs) & & CVB & 0.504 & 0.566 & 0.628 & 0.689 & 0.751 & 0.813 \\
\hline SID Tyr/SID Lys. (pigs) & & CVB & 0.349 & 0.393 & 0.436 & 0.480 & 0.523 & 0.567 \\
\hline Fe total & $\mathrm{mg}$ & & 262.907 & 265.459 & 268.011 & 270.562 & 273.114 & 275.666 \\
\hline Cu total & $\mathrm{mg}$ & & 18.684 & 18.906 & 19.128 & 19.350 & 19.572 & 19.794 \\
\hline Zn total & $\mathrm{mg}$ & & 106.067 & 106.517 & 106.968 & 107.418 & 107.869 & 108.319 \\
\hline Mn total & $\mathrm{mg}$ & & 80.331 & 80.419 & 80.508 & 80.596 & 80.685 & 80.773 \\
\hline Se total & $\mathrm{mg}$ & & 0.490 & 0.483 & 0.475 & 0.468 & 0.460 & 0.453 \\
\hline Co total & $\mathrm{mg}$ & & 0.149 & 0.154 & 0.159 & 0.164 & 0.169 & 0.174 \\
\hline I total & $\mathrm{mg}$ & & 4.109 & 4.110 & 4.111 & 4.111 & 4.112 & 4.113 \\
\hline Vitamin A & IU & & 7500.000 & 7500.000 & 7500.000 & 7500.000 & 7500.000 & 7500.000 \\
\hline Vitamin D3 & IU & & 1500.000 & 1500.000 & 1500.000 & 1500.000 & 1500.000 & 1500.000 \\
\hline Vitamin $\mathrm{E}$ & $\mathrm{mg}$ & & 60.000 & 60.000 & 60.000 & 60.000 & 60.000 & 60.000 \\
\hline
\end{tabular}




\section{Phase 2}

Treatment

Bestmix code

Price formulation ( $\mathrm{C} /$ ton)

\section{Ingredients}

Vleesvark. 0.75/0.5\%
Barley

Corn

Soybean meal HP

Wheat middlings

Salt

Limestone

L-Valine

Potassium carbonate $56 \%$

L-Threonine

L-Tryptophan

Monocalciumphosphate

Sodium Bicarbonate

$24.1 \%$

Fats/oils, Palm oil

L-Lysine $\mathrm{HCL}$

DL-Methionine

\section{Nutrients}

Dry matter

Moisture

Crude protein

Crude fat

Ash

Starch (Ewers)

Calcium

Phosphorous $\mathrm{P}$

Magnesium

Sodium

Potassium

Chloride

EW (energy value pigs)

SID Lysine (pigs)

SID Methionine (pigs)

SID Cysteine (pigs)

SID Meth.+Cyst. (pigs)

SID Threonine (pigs)

SID Tryptophan (pigs)

SID Isoleucine (pigs)

SID Leucine (pigs)

SID Valine (pigs)

SID Arginine (pigs)

SID Histidine (pigs)

SID Phenylalanine (pigs)

SID Tyrosine (pigs)

SID Threo./SID Lys. (pigs)

SID Trypt./SID Lys. (pigs)

SID Val./SID Lys. (pigs) - $\quad$ CVB

SID Isoleu./SID Lys.

(pigs)

SID Meth./SID Lys. (pigs)
$\mathbf{A}+\mathbf{G}$

$101 / 570.10$

1

$220.46 \quad 218.802$

217.14

215.48

6

213.82

$.01 / 570.10$

212.17

$\begin{array}{rr}0.500 & 0.50 \\ 36.500 & 35.92 \\ 47.605 & 45.08 \\ 0.000 & 2.82 \\ 10.374 & 10.79 \\ 0.249 & 0.28 \\ 1.223 & 1.22 \\ 0.152 & 0.12 \\ 0.429 & 0.34 \\ 0.260 & 0.21 \\ 0.067 & 0.05 \\ 0.748 & 0.67 \\ 0.331 & 0.26 \\ 0.700 & 0.93 \\ 0.703 & 0.61 \\ 0.159 & 0.13\end{array}$

0.500
35.352
42.563
5.645
11.224
0.324
1.228
0.091
0.257
0.178
0.040
0.602
0.199
1.175
0.518
0.104

0.500

0.500

0.500

34.777

34.203

40.042

8.468

37.521

11.650

0.361

1.230

0.061

0.172

0.138

0.027

0.528

0.132

1.413

0.425

0.076

89.129

89.031

10.871

10.969

88.934

10.900

11.900

11.066

88.836

11.164

13.900

3.957

4.517

50.407

0.612

0.516

0.129

0.190

0.670

0.347

1.100

0.800

0.310

0.170

0.480

0.520

0.144

0.276

0.749

0.536

0.438

0.216

0.395

0.274

0.650

0.180

0.670

0.345

0.387
3.800

3.644

4.523

48.760

0.610

0.514

0.138

0.188

0.675

0.350

1.100

0.800

0.296

47.112

0.184

0.480

0.520

0.146

0.326

0.556

0.528

0.245

0.450

0.313

0.182

0.695

0.407

0.370
4.529

0.608

0.511

0.146

0.186

0.680

0.353

1.100

0.800

0.283

0.197

0.480

0.520

0.148

0.376

0.888

0.576

0.618

0.273

0.505

0.351

0.650

0.184

0.720

0.470

4.535

45.465

0.606

0.509

0.155

0.184

0.686

0.355

1.100

0.800

0.269

0.211

0.480

0.520

0.149

0.425

0.957

0.596

0.709

0.302

0.559

0.390

0.650

0.187

0.745

0.532

0.353
11.290

12.075

0.399

1.233

0.030

0.086

0.097

0.013

0.455

0.066

1.650

0.333

0.049

88.739

11.261

14.900

4.113

4.541

43.817

0.604

0.506

0.163

0.182

0.691

0.358

1.100

0.800

0.256

0.224

0.480

0.520

0.151

0.475

1.027

0.616

0.799

0.330

0.614

0.428

0.650

0.189

0.770

0.595

0.319
33.629

35.000

14.113

12.500

0.436

1.235

0.000

0.000

0.056

0.000

0.382

0.000

1.888

0.240

0.021

88.641

11.359

15.900

4.269

4.547

42.170

0.602

0.504

0.172

0.180

0.696

0.361

1.100

0.800

0.242

0.238

0.480

0.520

0.153

0.525

1.096 


\begin{tabular}{|c|c|c|c|c|c|c|c|c|}
\hline $\begin{array}{l}\text { SID M+Cyst./SID Lys. } \\
\text { (pigs) }\end{array}$ & - & CVB & 0.600 & 0.600 & 0.600 & 0.600 & 0.600 & 0.600 \\
\hline SID Leu/SID Lys. (pigs) & & CVB & 0.936 & 1.023 & 1.110 & 1.197 & 1.283 & 1.370 \\
\hline SID His/SID Lys. (pigs) & & CVB & 0.270 & 0.306 & 0.342 & 0.377 & 0.413 & 0.449 \\
\hline SID Arg/SID Lys. (pigs) & & CVB & 0.548 & 0.660 & 0.773 & 0.886 & 0.999 & 1.111 \\
\hline SID Phe/SID Lys. (pigs) & & CVB & 0.494 & 0.562 & 0.631 & 0.699 & 0.768 & 0.836 \\
\hline SID Tyr/SID Lys. (pigs) & & CVB & 0.343 & 0.391 & 0.439 & 0.487 & 0.536 & 0.584 \\
\hline Fe total & $\begin{array}{l}\mathrm{m} \\
\mathrm{g}\end{array}$ & & 216.347 & 213.771 & 211.194 & 208.618 & 206.041 & 203.465 \\
\hline Cu total & $\begin{array}{l}\mathrm{m} \\
\mathrm{g}\end{array}$ & & 13.336 & 13.617 & 13.899 & 14.180 & 14.462 & 14.743 \\
\hline Zn total & $\mathrm{m}$ & & 80.766 & 81.873 & 82.981 & 84.088 & 85.196 & 86.303 \\
\hline Mn total & $\begin{array}{l}\mathrm{m} \\
\mathrm{g}\end{array}$ & & 60.369 & 61.711 & 63.053 & 64.395 & 65.737 & 67.079 \\
\hline Se total & $\mathrm{m}$ & & 0.393 & 0.392 & 0.391 & 0.390 & 0.389 & 0.388 \\
\hline Co total & $\mathrm{m}$ & & 0.141 & 0.145 & 0.150 & 0.154 & 0.159 & 0.163 \\
\hline I total & $\begin{array}{l}\mathrm{m} \\
\mathrm{g}\end{array}$ & & 2.773 & 2.772 & 2.771 & 2.771 & 2.770 & 2.769 \\
\hline Vitamin A & IU & & 5000.000 & 5000.000 & 5000.000 & 5000.000 & 5000.000 & 5000.000 \\
\hline Vitamin D3 & IU & & 1000.000 & 1000.000 & 1000.000 & 1000.000 & 1000.000 & 1000.000 \\
\hline Vitamin E & $\begin{array}{l}\mathrm{m} \\
\mathrm{g}\end{array}$ & & 40.000 & 40.000 & 40.000 & 40.000 & 40.000 & 40.000 \\
\hline
\end{tabular}


Phase 3

\section{Treatment}

$\mathbf{B}+\mathbf{H}$

C+I

D+J

$E+K$

$\mathbf{F}+\mathbf{L}$

$101 / 570.101$

234.47

\section{Bestmix code}

Price formulation ( $\mathcal{C} /$ ton)

\section{Ingredients}

Vleesvark. 0.75/0.5\%

Soybean hulls

Barley

Corn

Soybean meal HP

Wheat middlings

Salt

Limestone

Fibrecell

L-Valine

Potassium carbonate $56 \%$

L-Threonine

L-Tryptophan

Monocalciumphosphate

Sodium Bicarbonate 24.1\%

Fats/oils, Palm oil

L-Lysine $\mathrm{HCL}$

DL-Methionine
229.337$$
222.600
$$

215.864

0.500
5.880
25.976
57.405
1.591
2.240
0.346
0.738
1.680
0.110
0.333
0.191
0.058
0.806
0.462
1.016
0.556
0.112

0.500

4.410

26.322

54.304

3.679

5.180

0.342

0.774

1.260

2.000

0.131

0.396

0.219

0.069

0.878

0.518

1.000

0.616

0.133

utrients

Dry matter
Moisture
Crude protein

\begin{tabular}{lr}
$\%$ & 89.325 \\
$\%$ & 10.675 \\
\hline & 9.550 \\
\hline$\%$ & 3.942 \\
\hline
\end{tabular}

\begin{tabular}{rr}
89.237 & 89.122 \\
10.763 & 10.879 \\
10.310 & 11.308 \\
\hline 3.921 & 3.894
\end{tabular}

0.500
2.940
26.668
51.203
5.766
8.120
0.337
0.811
0.840
0.055
0.166
0.117
0.029
0.618
0.315
1.059
0.397
0.058

89.006
10.994
12.305
3.867

$\begin{array}{rr}0.500 & 0.500 \\ 1.470 & 0.000 \\ 27.014 & 27.360 \\ 48.101 & 45.000 \\ 7.854 & 9.942 \\ 11.060 & 14.000 \\ 0.333 & 0.328 \\ 0.847 & 0.884 \\ 0.420 & 0.000 \\ 0.028 & 0.000 \\ 0.083 & 0.000 \\ 0.080 & 0.043 \\ 0.014 & 0.000 \\ 0.524 & 0.430 \\ 0.242 & 0.168 \\ 1.081 & 1.102 \\ 0.318 & 0.239 \\ 0.031 & 0.004 \\ & \\ 88.891 & 88.775 \\ 11.110 & 11.225 \\ 13.303 & 14.300 \\ 3.840 & 3.813\end{array}$


Ash

Starch (Ewers)

Calcium

Phosphorous P

Magnesium

Sodium

Potassium

Chloride

EW (energy value pigs)

SID Lysine/EW

SID Lysine (pigs)

SID Methionine (pigs)

SID Cysteine (pigs)

SID Meth.+Cyst. (pigs)

SID Threonine (pigs)

SID Tryptophan (pigs)

SID Isoleucine (pigs)

SID Leucine (pigs)

SID Valine (pigs)

SID Arginine (pigs)

SID Histidine (pigs)

SID Phenylalanine (pigs)

SID Tyrosine (pigs)

SID Threo./SID Lys. (pigs)

SID Trypt./SID Lys. (pigs)

SID Val./SID Lys. (pigs)

SID Isoleu./SID Lys. (pigs)

SID Meth./SID Lys. (pigs)

SID M+Cyst./SID Lys. (pigs)

SID Leu/SID Lys. (pigs)

SID His/SID Lys. (pigs)

SID Arg/SID Lys. (pigs)

SID Phe/SID Lys. (pigs)

SID Tyr/SID Lys. (pigs)

\begin{tabular}{|c|c|c|}
\hline$\%$ & & 4.115 \\
\hline$\%$ & & 50.613 \\
\hline$\%$ & & 0.461 \\
\hline$\%$ & & 0.445 \\
\hline$\%$ & & 0.108 \\
\hline$\%$ & & 0.265 \\
\hline$\%$ & & 0.620 \\
\hline$\%$ & & 0.374 \\
\hline - & CVB & 1.103 \\
\hline & CVB & 0.632 \\
\hline$\%$ & CVB & 0.697 \\
\hline$\%$ & CVB & 0.270 \\
\hline$\%$ & CVB & 0.148 \\
\hline$\%$ & CVB & 0.418 \\
\hline$\%$ & CVB & 0.453 \\
\hline$\%$ & CVB & 0.125 \\
\hline$\%$ & CVB & 0.247 \\
\hline$\%$ & CVB & 0.739 \\
\hline$\%$ & CVB & 0.467 \\
\hline$\%$ & CVB & 0.358 \\
\hline$\%$ & CVB & 0.193 \\
\hline$\%$ & CVB & 0.353 \\
\hline$\%$ & CVB & 0.255 \\
\hline - & CVB & 0.650 \\
\hline- & CVB & 0.180 \\
\hline - & CVB & 0.670 \\
\hline- & CVB & 0.355 \\
\hline- & CVB & 0.388 \\
\hline- & CVB & 0.600 \\
\hline & CVB & 1.060 \\
\hline & CVB & 0.277 \\
\hline & CVB & 0.514 \\
\hline & CVB & 0.506 \\
\hline & CVB & 0.366 \\
\hline
\end{tabular}

$\begin{array}{rrrrr}4.105 & 4.092 & 4.080 & 4.067 & 4.054 \\ 49.769 & 48.660 & 47.552 & 46.443 & 45.335 \\ 0.461 & 0.461 & 0.462 & 0.462 & 0.462 \\ 0.455 & 0.468 & 0.481 & 0.494 & 0.507 \\ 0.117 & 0.129 & 0.140 & 0.152 & 0.164 \\ 0.251 & 0.234 & 0.216 & 0.198 & 0.180 \\ 0.621 & 0.623 & 0.625 & 0.626 & 0.628 \\ 0.362 & 0.346 & 0.331 & 0.315 & 0.299 \\ 1.103 & 1.102 & 1.101 & 1.101 & 1.100 \\ 0.632 & 0.632 & 0.632 & 0.632 & 0.632 \\ 0.697 & 0.696 & 0.696 & 0.695 & 0.695 \\ 0.260 & 0.247 & 0.235 & 0.222 & 0.209 \\ 0.160 & 0.175 & 0.190 & 0.205 & 0.220 \\ 0.420 & 0.422 & 0.424 & 0.427 & 0.429 \\ 0.453 & 0.453 & 0.452 & 0.452 & 0.452 \\ 0.126 & 0.127 & 0.128 & 0.129 & 0.130 \\ 0.280 & 0.324 & 0.368 & 0.411 & 0.455 \\ 0.785 & 0.845 & 0.905 & 0.966 & 1.026 \\ 0.483 & 0.505 & 0.526 & 0.548 & 0.569 \\ 0.424 & 0.510 & 0.596 & 0.682 & 0.768 \\ 0.214 & 0.242 & 0.270 & 0.297 & 0.325 \\ 0.391 & 0.441 & 0.491 & 0.541 & 0.591 \\ 0.281 & 0.315 & 0.348 & 0.382 & 0.416 \\ 0.650 & 0.650 & 0.650 & 0.650 & 0.650 \\ 0.181 & 0.183 & 0.185 & 0.186 & 0.188 \\ 0.694 & 0.725 & 0.756 & 0.788 & 0.819 \\ 0.403 & 0.466 & 0.528 & 0.591 & 0.654 \\ 0.374 & 0.355 & 0.337 & 0.318 & 0.300 \\ 0.603 & 0.606 & 0.610 & 0.613 & 0.617 \\ 1.127 & 1.214 & 1.301 & 1.389 & 1.476 \\ 0.307 & 0.347 & 0.387 & 0.427 & 0.468 \\ 0.608 & 0.732 & 0.856 & 0.981 & 1.105 \\ 0.561 & 0.633 & 0.706 & 0.778 & 0.850 \\ 0.403 & 0.452 & 0.501 & 0.550 & 0.599\end{array}$

$\begin{array}{rrrrr}4.105 & 4.092 & 4.080 & 4.067 & 4.054 \\ 49.769 & 48.660 & 47.552 & 46.443 & 45.335 \\ 0.461 & 0.461 & 0.462 & 0.462 & 0.462 \\ 0.455 & 0.468 & 0.481 & 0.494 & 0.507 \\ 0.117 & 0.129 & 0.140 & 0.152 & 0.164 \\ 0.251 & 0.234 & 0.216 & 0.198 & 0.180 \\ 0.621 & 0.623 & 0.625 & 0.626 & 0.628 \\ 0.362 & 0.346 & 0.331 & 0.315 & 0.299 \\ 1.103 & 1.102 & 1.101 & 1.101 & 1.100 \\ 0.632 & 0.632 & 0.632 & 0.632 & 0.632 \\ 0.697 & 0.696 & 0.696 & 0.695 & 0.695 \\ 0.260 & 0.247 & 0.235 & 0.222 & 0.209 \\ 0.160 & 0.175 & 0.190 & 0.205 & 0.220 \\ 0.420 & 0.422 & 0.424 & 0.427 & 0.429 \\ 0.453 & 0.453 & 0.452 & 0.452 & 0.452 \\ 0.126 & 0.127 & 0.128 & 0.129 & 0.130 \\ 0.280 & 0.324 & 0.368 & 0.411 & 0.455 \\ 0.785 & 0.845 & 0.905 & 0.966 & 1.026 \\ 0.483 & 0.505 & 0.526 & 0.548 & 0.569 \\ 0.424 & 0.510 & 0.596 & 0.682 & 0.768 \\ 0.214 & 0.242 & 0.270 & 0.297 & 0.325 \\ 0.391 & 0.441 & 0.491 & 0.541 & 0.591 \\ 0.281 & 0.315 & 0.348 & 0.382 & 0.416 \\ 0.650 & 0.650 & 0.650 & 0.650 & 0.650 \\ 0.181 & 0.183 & 0.185 & 0.186 & 0.188 \\ 0.694 & 0.725 & 0.756 & 0.788 & 0.819 \\ 0.403 & 0.466 & 0.528 & 0.591 & 0.654 \\ 0.374 & 0.355 & 0.337 & 0.318 & 0.300 \\ 0.603 & 0.606 & 0.610 & 0.613 & 0.617 \\ 1.127 & 1.214 & 1.301 & 1.389 & 1.476 \\ 0.307 & 0.347 & 0.387 & 0.427 & 0.468 \\ 0.608 & 0.732 & 0.856 & 0.981 & 1.105 \\ 0.561 & 0.633 & 0.706 & 0.778 & 0.850 \\ 0.403 & 0.452 & 0.501 & 0.550 & 0.599\end{array}$


Fe total

Cu total

Zn total

Mn total

Se total

Co total

I total

Vitamin A

Vitamin D3

Vitamin E

Vitamin K3 (3a711)

Vitamin B1

Vitamin B2

Vitamin B6

252.194
12.626
75.591
48.790
0.337
0.113
2.769
5000.000
1000.000
40.000
0.700
0.700
2.700
0.700

223.478
13.577
81.734
59.187
0.371
0.132
2.767
5000.000
1000.000
40.000
0.700
0.700
2.700
0.700

213.080

13.922

83.958

62.951

0.383

0.139

2.767

5000.000

1000.000

40.000

0.700

0.700

2.700

0.700
202.683

14.266

86.182

66.715

0.395

0.146

2.766

5000.000

1000.000

40.000

0.700

0.700

2.700 
Complete diet: analyses versus formulation

Note: $\quad$ Analyses performed at Provimi B.V. laboratory in Rotterdam

Values in red indicate deviation higher than measurement uncertainty for that specific analysis Crude protein determined by wet chemistry

\begin{tabular}{|c|c|c|c|c|c|c|c|c|c|c|c|c|c|c|c|c|c|c|}
\hline \multirow{2}{*}{\begin{tabular}{|r|} 
Phase \\
Treatment \\
Sample ID
\end{tabular}} & \multicolumn{6}{|c|}{1} & \multicolumn{6}{|c|}{2} & \multicolumn{6}{|c|}{3} \\
\hline & $\begin{array}{c}A+G \\
\text { GF1603-1 }\end{array}$ & $\begin{array}{c}\mathrm{B}+\mathrm{H} \\
\mathrm{GF} 1603-2\end{array}$ & $\begin{array}{c}\text { C+1 } \\
\text { GF1603-3 }\end{array}$ & $\begin{array}{c}\text { D+J } \\
\text { GF1603-4 }\end{array}$ & $\begin{array}{c}\text { E+K } \\
\text { GF1603-5 }\end{array}$ & $\begin{array}{c}F+L \\
G F 1603-6\end{array}$ & $\begin{array}{c}A+G \\
\text { GF1603-7 }\end{array}$ & $\begin{array}{c}\mathrm{B}+\mathrm{H} \\
\mathrm{GF1603-8}\end{array}$ & $\begin{array}{c}\text { C+1 } \\
\text { GF1603-9 }\end{array}$ & $\begin{array}{c}\text { D+J } \\
\text { GF1603-10 }\end{array}$ & $\begin{array}{c}\text { E+K } \\
\text { GF1603-11 }\end{array}$ & $\begin{array}{c}F+L \\
\text { GF1603-12 }\end{array}$ & $\begin{array}{c}A+G \\
\text { GF1603-13 }\end{array}$ & $\begin{array}{c}\text { B+H } \\
\text { GF1603-14 }\end{array}$ & $\begin{array}{c}\text { C+1 } \\
\text { GF1603-15 }\end{array}$ & $\begin{array}{c}D+J \\
\text { GF1603-16 }\end{array}$ & $\begin{array}{c}\text { E+K } \\
\text { GF1603-17 }\end{array}$ & $\begin{array}{c}F+L \\
\text { GF1603-18 }\end{array}$ \\
\hline \multicolumn{19}{|c|}{ 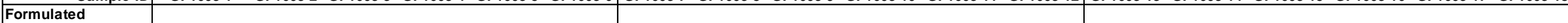 } \\
\hline Crude protein (\%) & 12.50 & 13.50 & 14.50 & 15.50 & 16.50 & 17.50 & 10.90 & 11.90 & 12.90 & 13.90 & 14.90 & 15.90 & 9.55 & 10.31 & 11.31 & 12.31 & 13.30 & 14.30 \\
\hline Crude fat (\%) & 3.45 & 3.51 & 3.56 & 3.62 & 3.67 & 3.72 & 3.49 & 3.64 & 3.80 & 3.96 & 4.11 & 4.27 & 3.94 & 3.92 & 3.89 & 3.87 & 3.84 & 3.81 \\
\hline Crude fibre (\%) & 3.74 & 3.72 & 3.70 & 3.68 & 3.66 & 3.64 & 3.79 & 3.87 & 3.95 & 4.03 & 4.11 & 4.19 & 4.59 & 4.62 & 4.66 & 4.69 & 4.73 & 4.76 \\
\hline Moisture (\%) & 11.0 & 11.1 & 11.2 & 11.3 & 11.4 & 11.6 & 10.87 & 10.97 & 11.07 & 11.16 & 11.26 & 11.36 & 10.68 & 10.76 & 10.88 & 10.99 & 11.11 & 11.23 \\
\hline Calcium (\%) & 0.61 & 0.61 & 0.61 & 0.61 & 0.61 & 0.61 & 0.61 & 0.61 & 0.61 & 0.61 & 0.60 & 0.60 & 0.46 & 0.46 & 0.46 & 0.46 & 0.46 & 0.46 \\
\hline Phosphorus (\%) & 0.52 & 0.52 & 0.52 & 0.52 & 0.52 & 0.53 & 0.52 & 0.51 & 0.51 & 0.51 & 0.51 & 0.50 & 0.45 & 0.45 & 0.47 & 0.48 & 0.49 & 0.51 \\
\hline Sodium (\%) & 0.18 & 0.18 & 0.18 & 0.18 & 0.18 & 0.18 & 0.19 & 0.19 & 0.19 & 0.18 & 0.18 & 0.18 & 0.27 & 0.25 & 0.23 & 0.22 & 0.20 & 0.18 \\
\hline Potassium (\%) & 0.67 & 0.68 & 0.70 & 0.71 & 0.73 & 0.74 & 0.67 & 0.68 & 0.68 & 0.69 & 0.69 & 0.70 & 0.62 & 0.62 & 0.62 & 0.62 & 0.63 & 0.63 \\
\hline \multicolumn{19}{|l|}{ Analyzed } \\
\hline Crude protein (\%) & 12.9 & 13.9 & 14.8 & 15.9 & 16.4 & 18.1 & 11.1 & 11.8 & 12.6 & 14.2 & 14.7 & 15.6 & 10.0 & 10.3 & 11.4 & 12.90 & 14.1 & 14.6 \\
\hline Crude fat (\%) & 4.0 & 3.9 & 4.0 & 4.0 & 3.9 & 3.8 & 4.3 & 4.8 & 4.7 & 4.8 & 5.0 & 5.3 & 4.8 & 4.9 & 5.0 & 5.00 & 4.9 & 4.9 \\
\hline Crude fibre (\%) & 3.2 & 3.2 & 3.2 & 3.2 & 3.2 & 3.3 & 3.7 & 3.8 & 3.8 & 3.8 & 3.9 & 4.0 & 3.7 & 3.7 & 3.8 & 3.70 & 3.6 & 3.6 \\
\hline Moisture (\%) & 11.4 & 11.0 & 11.5 & 11.7 & 11.5 & 11.0 & 12.1 & 11.5 & 12.2 & 11.9 & 11.7 & 11.5 & 11.1 & 10.7 & 10.8 & 10.80 & 10.7 & 10.7 \\
\hline Calcium (\%) & 0.64 & 0.64 & 0.63 & 0.62 & 0.63 & 0.66 & 0.64 & 0.66 & 0.62 & 0.62 & 0.63 & 0.63 & 0.50 & 0.50 & 0.49 & 0.49 & 0.49 & 0.49 \\
\hline Phosphorus (\%) & 0.56 & 0.52 & 0.53 & 0.53 & 0.54 & 0.57 & 0.55 & 0.57 & 0.56 & 0.56 & 0.56 & 0.55 & 0.49 & 0.51 & 0.52 & 0.54 & 0.56 & 0.58 \\
\hline Sodium (\%) & 0.19 & 0.18 & 0.20 & 0.19 & 0.19 & 0.19 & 0.19 & 0.20 & 0.19 & 0.18 & 0.18 & 0.18 & 0.29 & 0.28 & 0.24 & 0.23 & 0.21 & 0.19 \\
\hline Potassium (\%) & 0.69 & 0.69 & 0.71 & 0.72 & 0.75 & 0.79 & 0.68 & 0.71 & 0.71 & 0.71 & 0.72 & 0.73 & 0.65 & 0.67 & 0.67 & 0.69 & 0.69 & 0.71 \\
\hline \multicolumn{19}{|c|}{;us formulation (\%) } \\
\hline Crude protein (\%) & 103 & 103 & 102 & 103 & 99 & 103 & 102 & 99 & 98 & 102 & 99 & 98 & 105 & 100 & 101 & 105 & 106 & 102 \\
\hline Crude fat (\%) & 116 & 111 & 112 & 111 & 106 & 102 & 124 & 130 & 123 & 122 & 122 & 123 & 122 & 125 & 128 & 129 & 128 & 129 \\
\hline Crude fibre (\%) & 86 & 86 & 86 & 87 & 87 & 91 & 99 & 98 & 96 & 93 & 95 & 94 & 81 & 80 & 82 & 79 & 76 & 76 \\
\hline Moisture (\%) & 104 & 99 & 103 & 103 & 100 & 95 & 111 & 105 & 111 & 107 & 104 & 101 & 104 & 99 & 99 & 98 & 96 & 95 \\
\hline Calcium (\%) & 104 & 104 & 103 & 101 & 103 & 108 & 104 & 108 & 102 & 102 & 105 & 104 & 108 & 108 & 106 & 106 & 106 & 106 \\
\hline Phosphorus (\%) & 108 & 100 & 102 & 101 & 103 & 108 & 107 & 110 & 110 & 110 & 111 & 110 & 110 & 112 & 111 & 112 & 113 & 114 \\
\hline Sodium (\%) & 106 & 100 & 111 & 106 & 106 & 106 & 101 & 106 & 102 & 97 & 101 & 99 & 109 & 111 & 103 & 107 & 106 & 106 \\
\hline Potassium (\%) & 103 & 101 & 102 & 101 & 103 & 107 & 101 & 105 & 104 & 103 & 104 & 104 & 105 & 108 & 108 & 110 & 110 & 113 \\
\hline
\end{tabular}


$\underline{\text { Total amino acids: analyses versus formulation }}$

Note: $\quad$ Amino acids analyzed at University of Missouri, USA

For phase 2, only treatments $A$ and $F$ (sample ID GF1603-7 and GF1603-12) were analyzed. Values from treatments

$B-E$ were extrapolated from those.

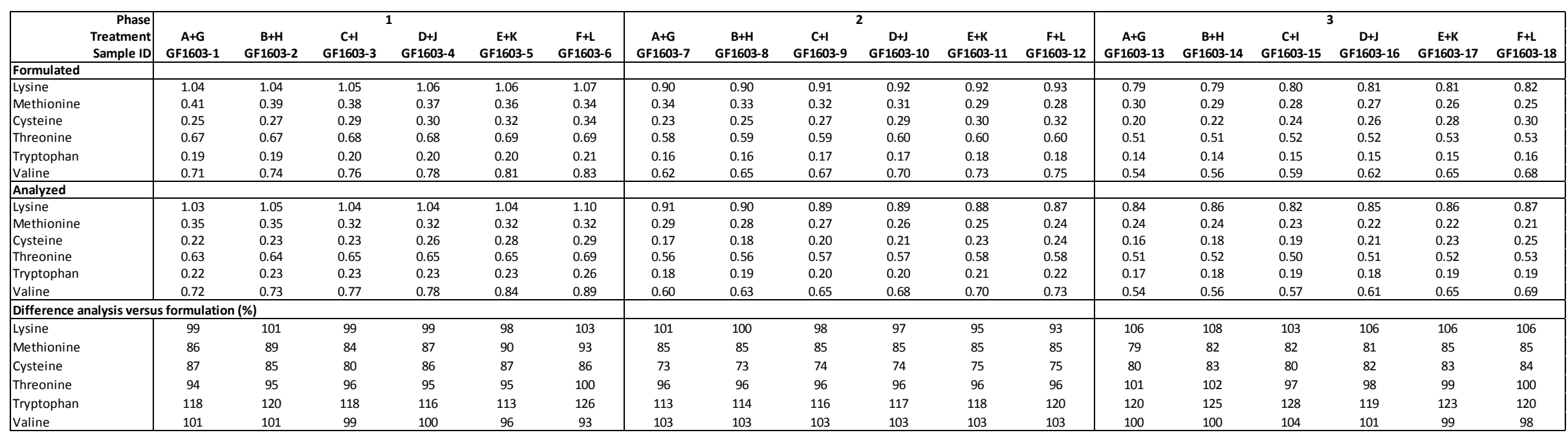


Note: $\quad$ ratios are extrapolated from above table.

Ratios marked yellow are below (INRA) requirement

\begin{tabular}{|c|c|c|c|c|c|c|c|c|c|c|c|c|c|c|c|c|c|c|}
\hline \multirow{3}{*}{\begin{tabular}{|r|} 
Phase \\
Treatment \\
Sample ID \\
\end{tabular}} & \multirow{3}{*}{$\begin{array}{c}\text { A+G } \\
\text { GF1603-1 }\end{array}$} & \multirow[b]{2}{*}{$\begin{array}{c}\text { B+H } \\
\text { GF1603-2 }\end{array}$} & \multicolumn{2}{|c|}{1} & \multirow[b]{2}{*}{$\begin{array}{c}E+K \\
\text { GF1603-5 }\end{array}$} & \multirow[b]{2}{*}{$\begin{array}{c}F+L \\
\text { GF1603-6 }\end{array}$} & \multirow[b]{2}{*}{$\begin{array}{c}A+G \\
\text { GF1603-7 }\end{array}$} & \multirow[b]{2}{*}{$\begin{array}{c}\text { B+H } \\
\text { GF1603-8 }\end{array}$} & \multicolumn{4}{|c|}{2} & \multicolumn{6}{|c|}{3} \\
\hline & & & $\begin{array}{c}\mathrm{C}+1 \\
\text { GF1603-3 }\end{array}$ & $\begin{array}{c}\text { D+J } \\
\text { GF1603-4 }\end{array}$ & & & & & $\begin{array}{c}\text { C+1 } \\
\text { GF1603-9 }\end{array}$ & $\begin{array}{c}\text { D+J } \\
\text { GF1603-10 }\end{array}$ & $\begin{array}{c}E+K \\
\text { GF1603-11 }\end{array}$ & $\begin{array}{c}F+L \\
\text { GF1603-12 }\end{array}$ & $\begin{array}{c}A+G \\
G F 1603-13\end{array}$ & $\begin{array}{c}\text { B+H } \\
\text { GF1603-14 }\end{array}$ & $\begin{array}{c}\text { C+1 } \\
\text { GF1603-15 }\end{array}$ & $\begin{array}{c}\text { D+J } \\
\text { GF1603-16 }\end{array}$ & $\begin{array}{c}E+K \\
\text { GF1603-17 }\end{array}$ & $\begin{array}{c}F+L \\
\text { GF1603-18 }\end{array}$ \\
\hline & & & & & & $101 / 570.105$ & $101 / 570.201$ & & & & $101 / 570.205$ & $101 / 570.205$ & $101 / 570.301$ & & & & & $101 / 570.305$ \\
\hline \multicolumn{19}{|l|}{ Formulated } \\
\hline SID Met/SID Lys & 0.40 & 0.38 & 0.37 & 0.36 & 0.34 & 0.33 & 0.39 & 0.37 & 0.35 & 0.34 & 0.32 & 0.30 & 0.39 & 0.37 & 0.36 & 0.34 & 0.32 & 0.30 \\
\hline SID M+C/SID Lys & 0.60 & 0.60 & 0.60 & 0.60 & 0.60 & 0.60 & 0.60 & 0.60 & 0.60 & 0.60 & 0.60 & 0.60 & 0.60 & 0.60 & 0.60 & 0.60 & 0.60 & 0.60 \\
\hline SID Thre/SID Lys & 0.65 & 0.65 & 0.65 & 0.65 & 0.65 & 0.65 & 0.65 & 0.65 & 0.65 & 0.65 & 0.65 & 0.65 & 0.65 & 0.65 & 0.65 & 0.65 & 0.65 & 0.65 \\
\hline SID Tryp/SID Lys & 0.18 & 0.18 & 0.18 & 0.18 & 0.18 & 0.18 & 0.18 & 0.18 & 0.18 & 0.19 & 0.19 & 0.19 & 0.18 & 0.18 & 0.18 & 0.18 & 0.19 & 0.19 \\
\hline SID Val/SID Lys & 0.67 & 0.69 & 0.71 & 0.72 & 0.74 & 0.76 & 0.67 & 0.70 & 0.72 & 0.75 & 0.77 & 0.80 & 0.67 & 0.69 & 0.73 & 0.76 & 0.79 & 0.82 \\
\hline \multicolumn{19}{|l|}{\begin{tabular}{|l} 
Analyzed \\
\end{tabular}} \\
\hline SID Met/SID Lys & 0.35 & 0.34 & 0.31 & 0.31 & 0.31 & 0.29 & 0.32 & 0.31 & 0.31 & 0.30 & 0.29 & 0.28 & 0.29 & 0.28 & 0.28 & 0.26 & 0.26 & 0.24 \\
\hline SID M+C/SID Lys & 0.52 & 0.52 & 0.50 & 0.53 & 0.54 & 0.52 & 0.48 & 0.48 & 0.49 & 0.50 & 0.51 & 0.52 & 0.45 & 0.46 & 0.47 & 0.46 & 0.48 & 0.48 \\
\hline SID Thre/SID Lys & 0.61 & 0.61 & 0.63 & 0.63 & 0.63 & 0.63 & 0.62 & 0.63 & 0.64 & 0.65 & 0.66 & 0.67 & 0.61 & 0.61 & 0.62 & 0.60 & 0.61 & 0.61 \\
\hline SID Val/SID Lys & 0.68 & 0.69 & 0.70 & 0.74 & 0.73 & 0.69 & 0.68 & 0.72 & 0.76 & 0.80 & 0.84 & 0.88 & 0.63 & 0.64 & 0.73 & 0.73 & 0.74 & 0.75 \\
\hline \multicolumn{19}{|c|}{\begin{tabular}{|l|l} 
Difference analysis versus formulation (\%) \\
\end{tabular}} \\
\hline SID Met/SID Lys & 87 & 88 & 85 & 88 & 92 & 90 & 83 & 85 & 86 & 88 & 90 & 91 & 75 & 76 & 80 & 77 & 80 & 80 \\
\hline SID M+C/SID Lys & 87 & 87 & 83 & 88 & 91 & 87 & 79 & 80 & 82 & 83 & 84 & 86 & 75 & 76 & 79 & 77 & 79 & 79 \\
\hline SID Thre/SID Lys & 94 & 94 & 97 & 97 & 97 & 97 & 95 & 96 & 98 & 100 & 101 & 103 & 95 & 94 & 95 & 93 & 93 & 94 \\
\hline SID Tryp/SID Lys & 118 & 120 & 119 & 117 & 116 & 122 & 111 & 114 & 118 & 121 & 125 & 128 & 113 & 115 & 125 & 113 & 116 & 113 \\
\hline SID Val/SID Lys & 102 & 100 & 99 & 102 & 98 & 90 & 102 & 103 & 105 & 107 & 109 & 110 & 94 & 93 & 101 & 96 & 94 & 92 \\
\hline
\end{tabular}


APPENDIX III: Results table performance

Main effects

\begin{tabular}{|c|c|c|c|c|c|c|c|c|c|c|c|c|c|c|}
\hline $\begin{array}{l}\text { Treatment } \\
\text { CP Level Phase } 1 \\
\text { CP Level Phase } 2 \\
\text { CP Level Phase } 3 \\
\end{array}$ & \begin{tabular}{r|}
$A+G$ \\
12.5 \\
10.9 \\
9.5 \\
\end{tabular} & $\begin{array}{l}\mathrm{B}+\mathrm{H} \\
13.5 \\
11.9 \\
10.3 \\
\end{array}$ & $\begin{array}{r}C+1 \\
14.5 \\
12.9 \\
11.3 \\
\end{array}$ & \begin{tabular}{r|}
$D+J$ \\
15.5 \\
13.9 \\
12.3 \\
\end{tabular} & \begin{tabular}{r|}
$E+K$ \\
16.5 \\
14.9 \\
13.3 \\
\end{tabular} & \begin{tabular}{r|}
$\mathrm{F}+\mathrm{L}$ \\
17.5 \\
15.9 \\
14.3 \\
\end{tabular} & SEM & $\begin{array}{c}P \\
\text { CP level }\end{array}$ & $\begin{array}{l}\text { P Linear } \\
\text { CP Level }\end{array}$ & $\begin{array}{c}\text { P } \\
\text { Quadratic } \\
\text { CP Level }\end{array}$ & Gilts & Barrows & SEM & $P$ sex \\
\hline \multicolumn{15}{|l|}{ Body weight (kg) } \\
\hline Day 0 & 30.12 & 30.18 & 29.93 & 30.00 & 30.18 & 30.12 & 1.88 & 0.941 & 0.949 & 0.558 & 29.39 & 30.78 & 1.874 & 0.000 \\
\hline Day 14 & 40.53 & 40.45 & 41.86 & 41.77 & 40.98 & 41.14 & 0.20 & 0.000 & 0.015 & 0.000 & 40.84 & 41.41 & 0.095 & 0.003 \\
\hline Day 27 & 51.36 & 52.42 & 54.87 & 54.23 & 53.35 & 53.58 & 0.38 & 0.000 & 0.000 & 0.000 & 52.77 & 53.83 & 0.297 & 0.000 \\
\hline Day 42 & 63.60 & 66.00 & 69.55 & 68.83 & 68.18 & 68.51 & 0.56 & 0.000 & 0.000 & 0.000 & 65.72 & 69.17 & 0.395 & 0.000 \\
\hline Day 57 & 75.67 & 79.15 & 83.38 & 83.09 & 82.26 & 82.72 & 0.83 & 0.000 & 0.000 & 0.000 & 78.30 & 83.79 & 0.575 & 0.000 \\
\hline Day 77 & 93.20 & 96.60 & 102.75 & 102.33 & 101.85 & 102.05 & 1.18 & 0.000 & 0.000 & 0.000 & 95.77 & 103.82 & 0.745 & 0.000 \\
\hline Day 98 & 109.98 & 116.23 & 121.57 & 121.34 & 122.09 & 122.74 & 1.48 & 0.000 & 0.000 & 0.000 & 114.09 & 123.90 & 0.953 & 0.000 \\
\hline \multicolumn{15}{|c|}{ Phase 1 (day 0-27) } \\
\hline ADG (gram) & 802.85 & 829.39 & 919.77 & 896.44 & 864.05 & 872.54 & 14.00 & 0.000 & 0.000 & 0.000 & 845.65 & 882.70 & 10.828 & 0.000 \\
\hline ADFI (gram) & 1637.49 & 1604.03 & 1731.10 & 1700.34 & 1646.12 & 1670.74 & 27.70 & 0.003 & 0.153 & 0.034 & 1628.73 & 1701.21 & 21.920 & 0.001 \\
\hline GF & 0.48 & 0.52 & 0.53 & 0.53 & 0.52 & 0.52 & 0.00 & 0.000 & 0.000 & 0.000 & 0.52 & 0.52 & 0.004 & 0.729 \\
\hline FCR & 2.08 & 1.94 & 1.88 & 1.90 & 1.91 & 1.92 & & 0.000 & .000 & 0.000 & 1.94 & 1.93 & & 0.729 \\
\hline Cost ( $€ /$ kg gain) & 0.49 & 0.45 & 0.44 & 0.44 & 0.44 & 0.44 & 0.00 & 0.000 & 000 & .000 & 0.45 & 0.45 & 0.003 & 0.809 \\
\hline \multicolumn{15}{|c|}{ Phase 2 (day 27-57) } \\
\hline ADG (gram) & 810.34 & 891.19 & 950.49 & 961.70 & 963.56 & 971.12 & 19.74 & 0.000 & 0.000 & 0.003 & 850.67 & 998.80 & 11.087 & 0.000 \\
\hline ADFI (gram) & 2345.93 & 2358.36 & 2512.02 & 2398.80 & 2427.52 & 2458.72 & 42.30 & 0.053 & 0.058 & 0.276 & 2214.61 & 2619.18 & 27.268 & 0.000 \\
\hline GF & 0.35 & 0.38 & 0.38 & 0.40 & 0.40 & 0.40 & 0.01 & 0.000 & 0.000 & 0.011 & 0.38 & 0.38 & 0.003 & 0.869 \\
\hline FCR & 2.82 & 2.65 & 2.63 & 2.49 & 2.52 & 2.52 & & 0.000 & 0.000 & 0.011 & 2.60 & 2.60 & & 0.869 \\
\hline Cost ( $€ /$ kg gain) & 0.62 & 0.58 & 0.57 & 0.54 & 0.54 & 0.54 & 0.01 & 0.000 & 0.000 & 0.007 & 0.56 & 0.57 & 0.004 & 0.957 \\
\hline \multicolumn{15}{|c|}{ Phase 3 (day 57-98) } \\
\hline ADG (gram) & 818.20 & 899.02 & 926.26 & 927.87 & 966.18 & 970.81 & 24.53 & 0.001 & 0.000 & 0.128 & 864.19 & 971.92 & 12.897 & 0.000 \\
\hline ADFI (gram) & 2497.85 & 2639.49 & 2762.41 & 2667.40 & 2827.12 & 2854.11 & 50.56 & 0.000 & 0.000 & 0.350 & 2438.04 & 2978.09 & 31.276 & 0.000 \\
\hline GF & 0.32 & 0.34 & 0.34 & 0.35 & 0.34 & 0.34 & 0.01 & 0.336 & 0.095 & 0.229 & 0.35 & 0.33 & 0.003 & 0.000 \\
\hline FCR & 3.08 & 2.92 & 2.97 & 2.90 & 2.91 & 2.92 & & 0.336 & 0.095 & 0.229 & 2.85 & 3.06 & & 0.000 \\
\hline Cost ( $€ /$ kg gain) & 0.73 & 0.67 & 0.66 & 0.62 & 0.61 & 0.60 & 0.01 & 0.000 & 0.000 & 0.161 & 0.62 & 0.67 & 0.006 & 0.000 \\
\hline \multicolumn{15}{|c|}{ Overall (day 0-98) } \\
\hline ADG (gram) & 814.02 & 877.80 & 932.23 & 929.92 & 937.61 & 944.19 & 15.09 & 0.000 & 0.000 & 0.000 & 855.94 & 955.98 & 9.722 & 0.000 \\
\hline ADFI (gram) & 198.22 & 2243.81 & 2362.96 & 2297.28 & 2349.80 & 2381.69 & 35.14 & 0.001 & 0.000 & 0.265 & 2129.60 & 2481.66 & 23.652 & 0.000 \\
\hline GF & 0.37 & 0.39 & 0.39 & 0.41 & 0.40 & 0.40 & 0.00 & 0.000 & 0.000 & 0.000 & 0.40 & 0.38 & 0.002 & 0.000 \\
\hline FCR & 2.73 & 2.55 & 2.53 & 2.46 & 2.50 & 2.51 & & 0.000 & 0.000 & 0.000 & 2.50 & 2.60 & & 0.000 \\
\hline Cost ( $€ /$ kg gain) & 0.63 & 0.58 & 0.57 & 0.54 & 0.54 & 0.53 & 0.01 & 0.000 & 0.000 & 0.000 & 0.55 & 0.57 & 0.003 & 0.000 \\
\hline
\end{tabular}

Note: GF data (mean, SEM and P-value) is obtained by statistical analyses, FCR data (means and P-value) is derived from GF. 


\section{Interactions}

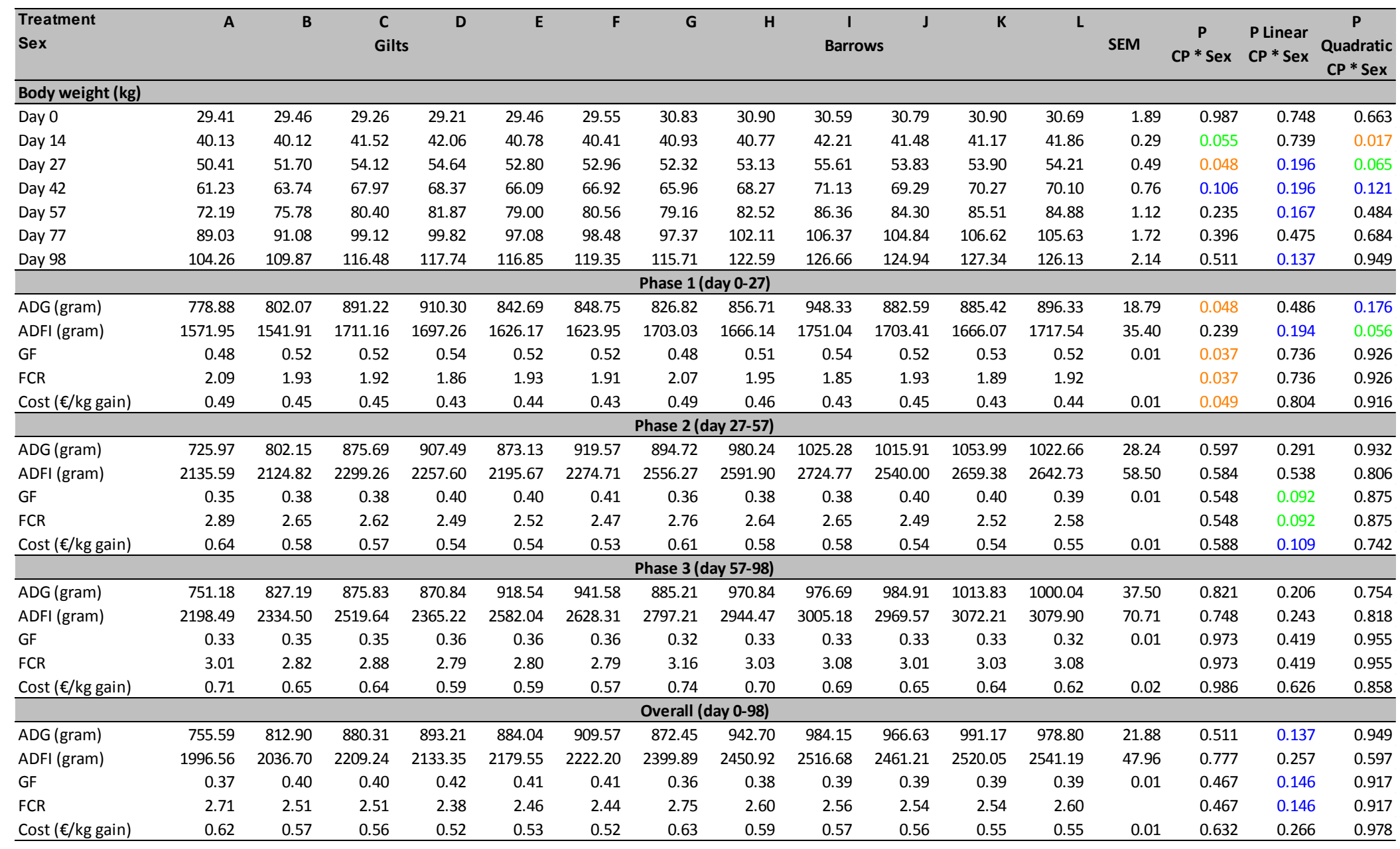

Note: GF data (mean, SEM and P-value) is obtained by statistical analyses, FCR data (means and P-value) is derived from GF. 
Phase 1

Note: Broken-line for barrows and gilts fitted separately due to interaction between CP level and sex.

Broken-line for ADFI in barrows could not be fitted due to lack of quadratic response.

ADG Male curvilinear fit - Crude Protein level \begin{tabular}{|l|l|l|l|}
\hline Paramet & Estimate & Approx & Approximate 95\%
\end{tabular}

\begin{tabular}{|l|r|r|r|r|}
\hline $\begin{array}{c}\text { Paramet } \\
\text { er }\end{array}$ & Estimate & $\begin{array}{c}\text { Approx } \\
\text { Std } \\
\text { Error }\end{array}$ & \multicolumn{2}{|c|}{$\begin{array}{c}\text { Approximate 95\% } \\
\text { Confidence } \\
\text { Limits }\end{array}$} \\
\hline $\mathbf{L}$ & 909.900 & 16.937 & 874.700 & 945.100 \\
\hline $\mathbf{U}$ & -15.407 & 29.094 & -75.910 & 45.097 \\
\hline $\mathbf{R}$ & 14.731 & 2.039 & 10.490 & 18.972 \\
\hline
\end{tabular}

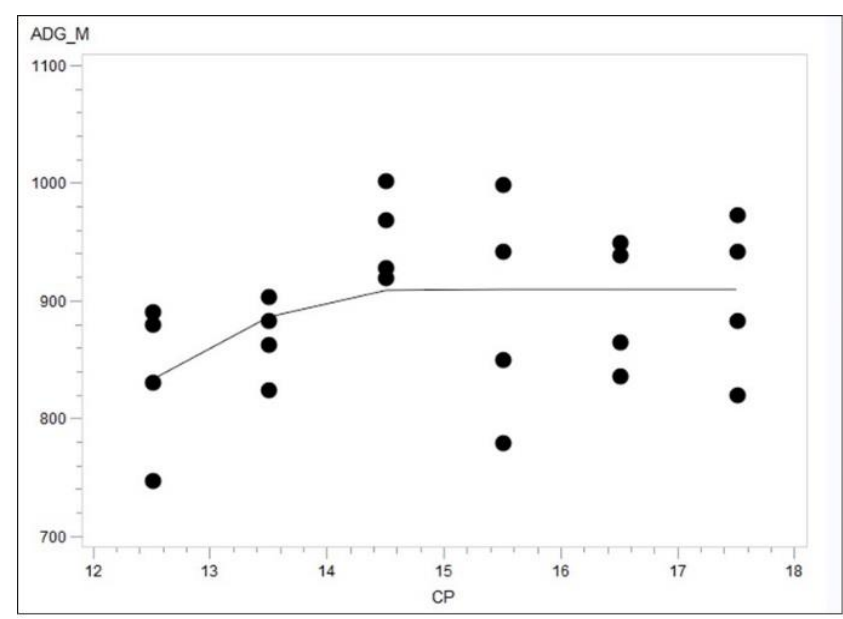

ADFI Male curvilinear fit - Crude Protein level

\begin{tabular}{|l|r|r|r|r|}
\hline $\begin{array}{c}\text { Paramet } \\
\text { er }\end{array}$ & Estimate & $\begin{array}{c}\text { Approx } \\
\text { Std } \\
\text { Error }\end{array}$ & \multicolumn{2}{|c|}{$\begin{array}{c}\text { Approximate 95\% } \\
\text { Confidence } \\
\text { Limits }\end{array}$} \\
\hline $\mathbf{L}$ & 1732.300 & 28.423 & 1673.500 & 1791.100 \\
\hline $\mathbf{U}$ & 0.560 &. &. & \\
\hline $\mathbf{R}$ & 11.433 & . & . & \\
\hline
\end{tabular}

GF Male curvilinear fit - Crude Protein level \begin{tabular}{|l|l|l|l|}
\hline Paramet & Estimate & Approx & Approximate 95\% \\
\hline
\end{tabular}

\begin{tabular}{|l|r|r|r|r|}
$\begin{array}{c}\text { er } \\
\text { er }\end{array}$ & & $\begin{array}{c}\text { Atd } \\
\text { Error }\end{array}$ & \multicolumn{2}{|c|}{$\begin{array}{c}\text { Confidence } \\
\text { Limits }\end{array}$} \\
\hline $\mathbf{L}$ & 0.525 & 0.004 & 0.516 & 0.534 \\
\hline $\mathbf{U}$ & -0.010 & 0.009 & -0.028 & 0.008 \\
\hline $\mathbf{R}$ & 14.610 & 0.913 & 12.711 & 16.509 \\
\hline
\end{tabular}
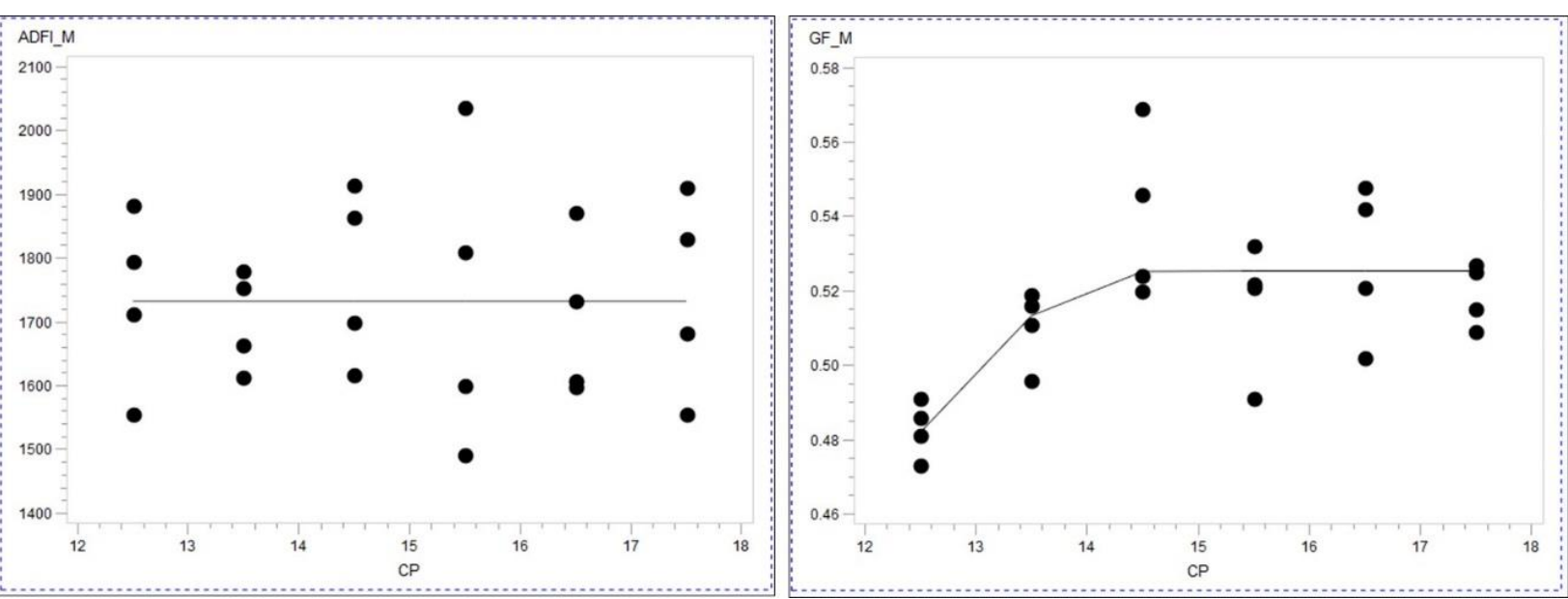
ADG Female curvilinear fit - Crude Protein level

Paramet Estimate Approx Approximate 95\%

er

\begin{tabular}{|l|r|r|r|r|} 
er & & \multicolumn{1}{c|}{$\begin{array}{c}\text { Std } \\
\text { Error }\end{array}$} & \multicolumn{2}{|c|}{$\begin{array}{c}\text { Confidence } \\
\text { Limits }\end{array}$} \\
\hline $\mathbf{L}$ & 855.100 & 24.064 & 804.900 & 905.300 \\
\hline $\mathbf{U}$ & -8.065 & 18.933 & -47.558 & 31.428 \\
\hline $\mathbf{R}$ & 15.562 & 3.348 & 8.578 & 22.547 \\
\hline
\end{tabular}
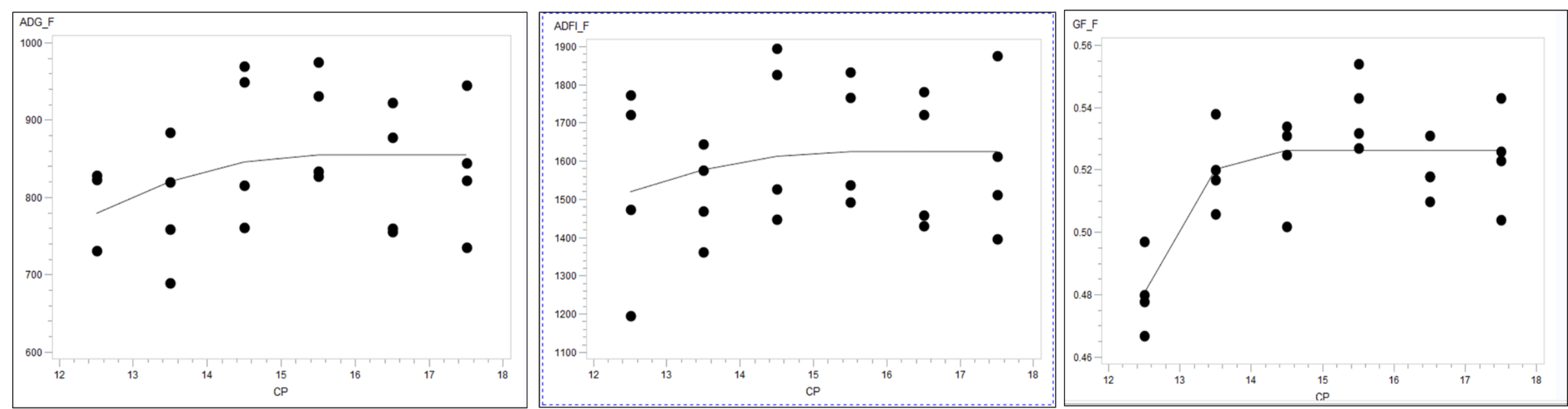

GF Female curvilinear fit - Lysine level

Paramet Estimate Approx Approximate 95\%$$
\text { er }
$$

\begin{tabular}{|l|r|r|r|r|} 
& & \multicolumn{1}{c|}{$\begin{array}{c}\text { Std } \\
\text { Error }\end{array}$} & \multicolumn{2}{|c|}{ Limits } \\
\hline $\mathbf{L}$ & 1625.100 & 54.676 & 1511.400 & 1738.800 \\
\hline $\mathbf{U}$ & -11.433 & 42.224 & -99.242 & 76.377 \\
\hline $\mathbf{R}$ & 15.533 & 5.351 & 4.405 & 26.661 \\
\hline
\end{tabular}

\begin{tabular}{|c|c|c|c|c|}
\hline . & & Error & \multicolumn{2}{|c|}{ Limits } \\
\hline $\mathbf{L}$ & 0.526 & 0.003 & 0.519 & 0.533 \\
\hline U & -0.019 & 0.013 & -0.046 & 0.009 \\
\hline $\mathbf{R}$ & 14.072 & 0.559 & 12.910 & 15.233 \\
\hline
\end{tabular}

Note: Broken-line for barrows and gilts fitted combined due to lack of interaction between CP level and sex.

40 | Wageningen Livestock Research Report 111 
ADG curvilinear fit - Crude Protein level

\begin{tabular}{|l|r|r|r|r}
\hline $\begin{array}{l}\text { Paramet } \\
\text { er }\end{array}$ & Estimate & $\begin{array}{r}\text { Approx } \\
\text { Std Error }\end{array}$ & \multicolumn{2}{|c}{$\begin{array}{r}\text { Approximate 95\% } \\
\text { Confidence } \\
\text { Limits }\end{array}$} \\
\hline $\mathbf{L}$ & 966.100 & 21.926 & 921.900 & 1010.200 \\
\hline $\mathbf{U}$ & -16.116 & 15.788 & -47.914 & 15.682 \\
\hline $\mathbf{R}$ & 14.012 & 1.465 & 11.062 & 16.963 \\
\hline
\end{tabular}

ADFI curvilinear fit - Crude Protein level

\begin{tabular}{|l|r|r|r|r}
\hline $\begin{array}{l}\text { Paramet } \\
\text { er }\end{array}$ & Estimate & $\begin{array}{r}\text { Approx } \\
\text { Std Error }\end{array}$ & \multicolumn{2}{|c|}{$\begin{array}{r}\text { Approximate 95\% } \\
\text { Confidence } \\
\text { Limits }\end{array}$} \\
\hline L & 2441.600 & 58.444 & 2323.800 & 2559.300 \\
\hline U & -17.788 & 76.682 & -172.200 & 136.700 \\
\hline R & 13.351 & 5.115 & 3.050 & 23.653 \\
\hline
\end{tabular}

GF curvilinear fit - Crude Protein level

\begin{tabular}{|l|r|r|r|r}
\hline $\begin{array}{l}\text { Paramet } \\
\text { er }\end{array}$ & Estimate & $\begin{array}{r}\text { Approx } \\
\text { Std Error }\end{array}$ & \multicolumn{2}{|c}{$\begin{array}{c}\text { Approximate 95\% } \\
\text { Confidence } \\
\text { Limits }\end{array}$} \\
\hline L & 0.398 & 0.004 & 0.389 & 0.406 \\
\hline $\mathbf{U}$ & -0.003 & 0.002 & -0.006 & 0.000 \\
\hline $\mathbf{R}$ & 14.751 & 1.060 & 12.613 & 16.888 \\
\hline
\end{tabular}

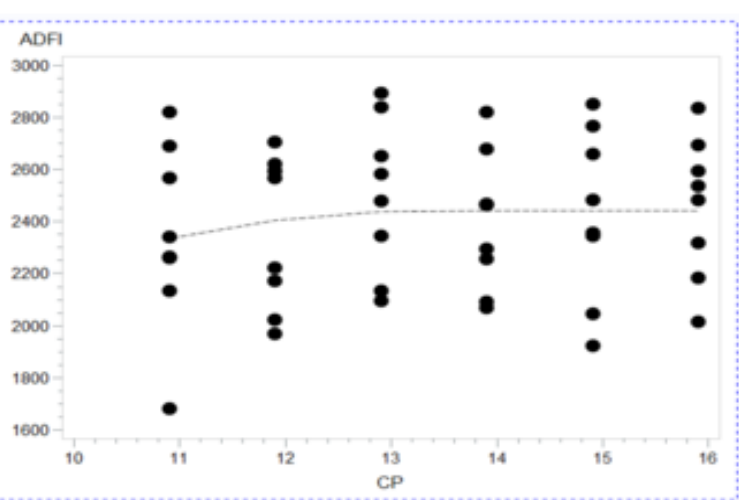

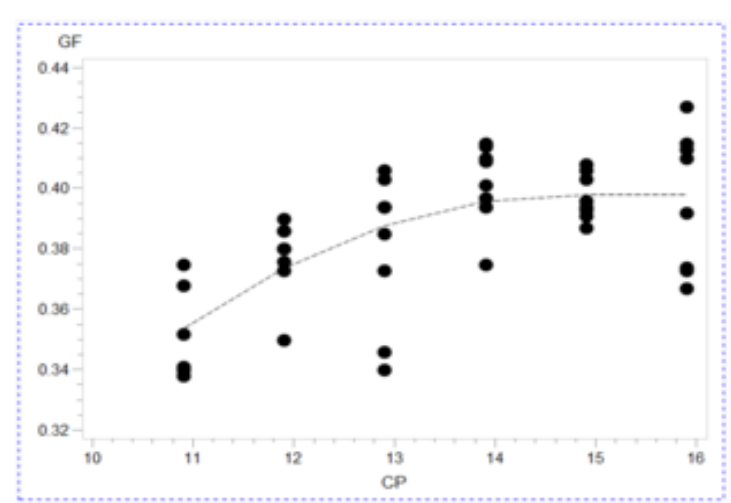


Phase 3

Note: Broken-line for barrows and gilts fitted separately due to linear response when combined. Broken-line for GF in barrows could not be fitted due to lack of quadratic response.

curvilinear models GF1603 Raw Data ADG_Male

\begin{tabular}{l|r|r|r|r}
\hline $\begin{array}{l}\text { Paramet } \\
\text { er }\end{array}$ & Estimate & $\begin{array}{r}\text { Approx } \\
\text { Std Error }\end{array}$ & $\begin{array}{r}\text { Approximate 95\% } \\
\text { Confidence } \\
\text { Limits }\end{array}$ \\
\hline $\mathbf{L}$ & 995.300 & 13.456 & 967.300 & 1023.300 \\
\hline $\mathbf{U}$ & -32.013 & 36.261 & -107.400 & 43.395 \\
\hline $\mathbf{R}$ & 11.140 & 1.008 & 9.044 & 13.237 \\
\hline
\end{tabular}

ADG $M$

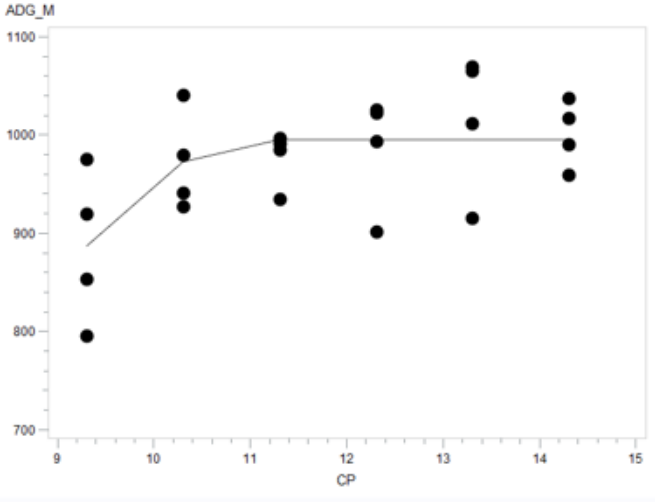

ADFI Male curvilinear fit - Crude Protein level

\begin{tabular}{|l|r|r|r|r|}
\hline $\begin{array}{l}\text { Paramet } \\
\text { er }\end{array}$ & Estimate & $\begin{array}{r}\text { Approx } \\
\text { Std Error }\end{array}$ & \multicolumn{2}{|c|}{$\begin{array}{c}\text { Approximate 95\% } \\
\text { Confidence } \\
\text { Limits }\end{array}$} \\
\hline L & 3057.200 & 46.789 & 2959.900 & 3154.500 \\
\hline $\mathbf{U}$ & -26.421 & 37.368 & -104.100 & 51.289 \\
\hline R & 12.293 & 2.017 & 8.099 & 16.488 \\
\hline
\end{tabular}

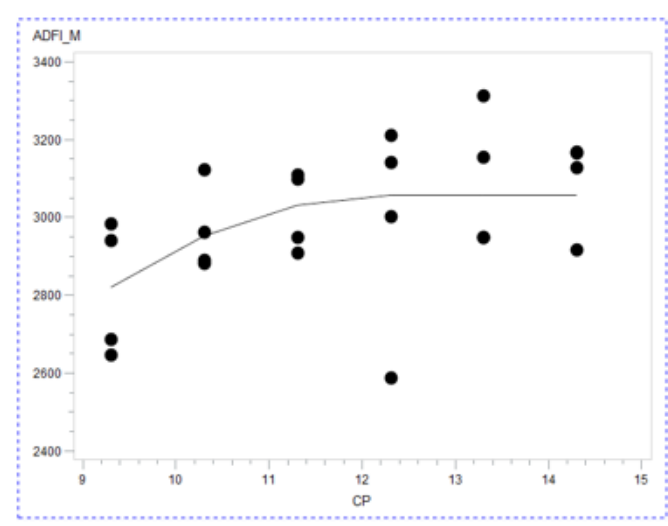

GF Male curvilinear fit - Crude Protein level

\begin{tabular}{|l|r|r|r|r|}
\hline $\begin{array}{l}\text { Paramet } \\
\text { er }\end{array}$ & Estimate & $\begin{array}{r}\text { Approx } \\
\text { Std Error }\end{array}$ & \multicolumn{2}{|c|}{$\begin{array}{l}\text { Approximate 95\% } \\
\text { Confidence } \\
\text { Limits }\end{array}$} \\
\hline L & 0.327 & 0.003 & 0.321 & 0.333 \\
\hline $\mathbf{U}$ & -0.013 & 0.008 & -0.029 & 0.003 \\
\hline R & 10.279 & & & \\
\hline
\end{tabular}

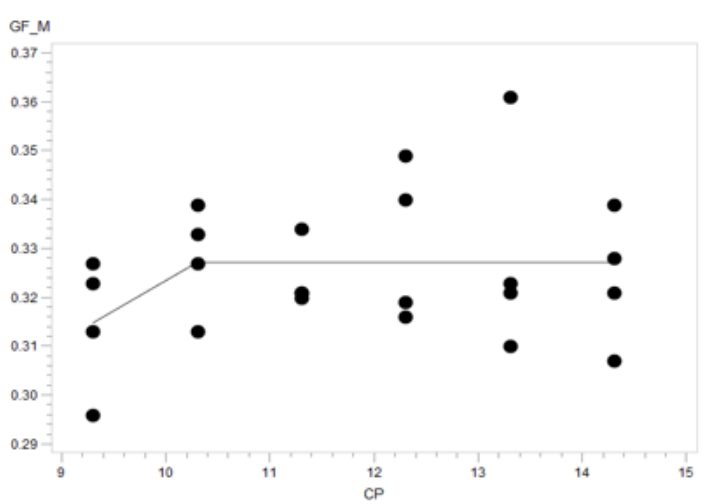




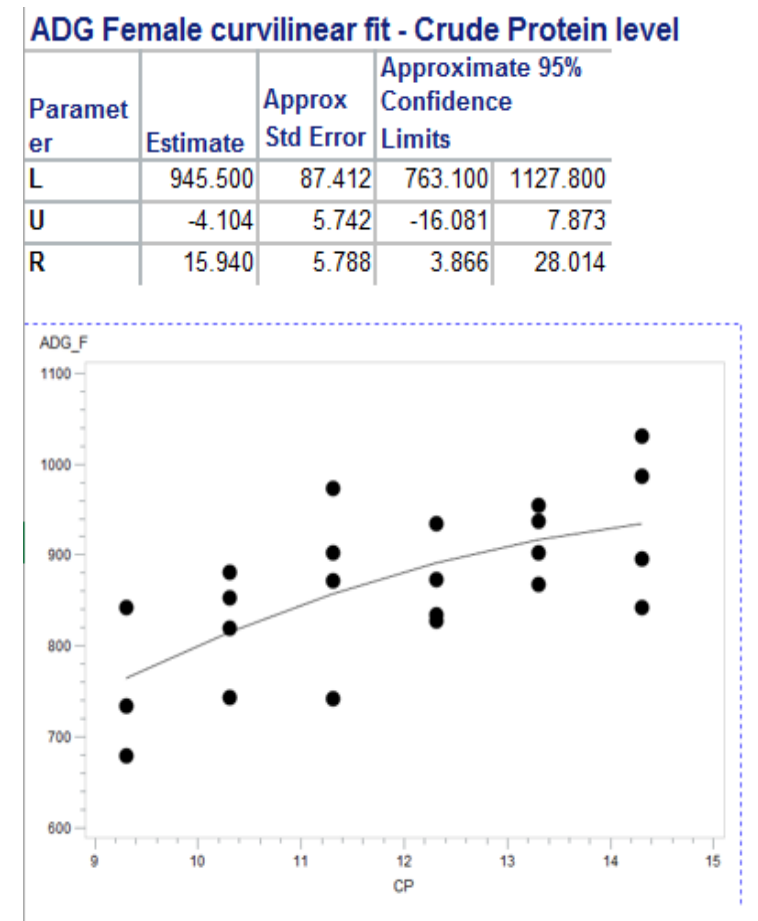

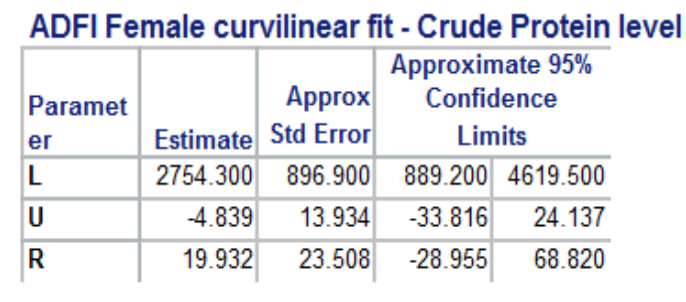

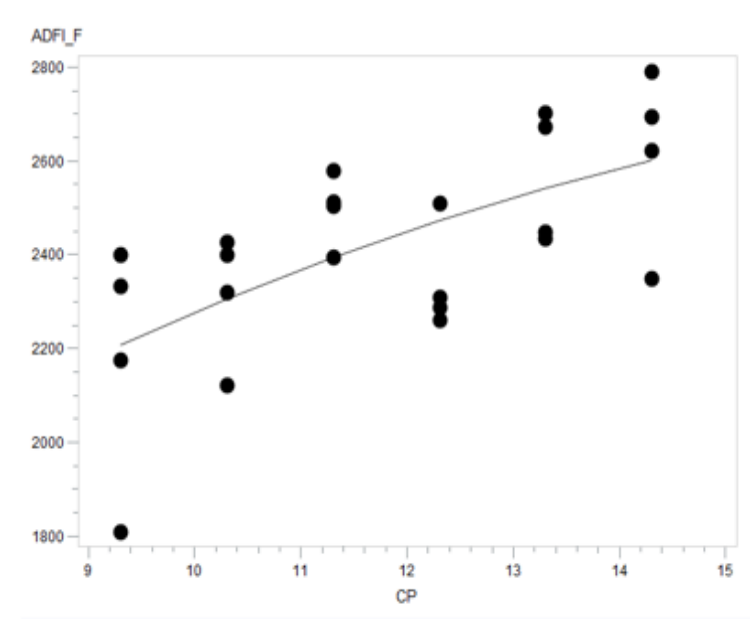

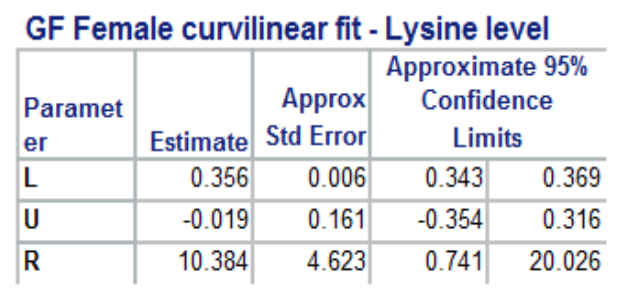

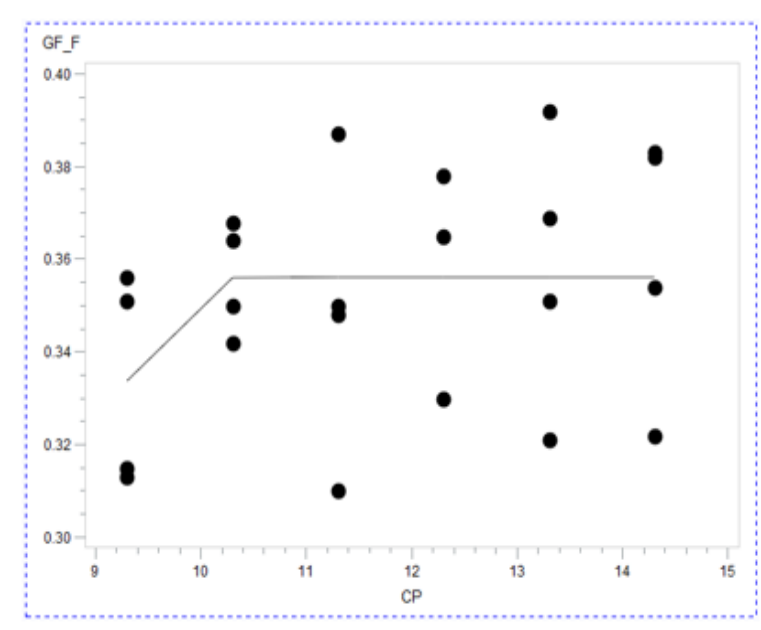


Main effects

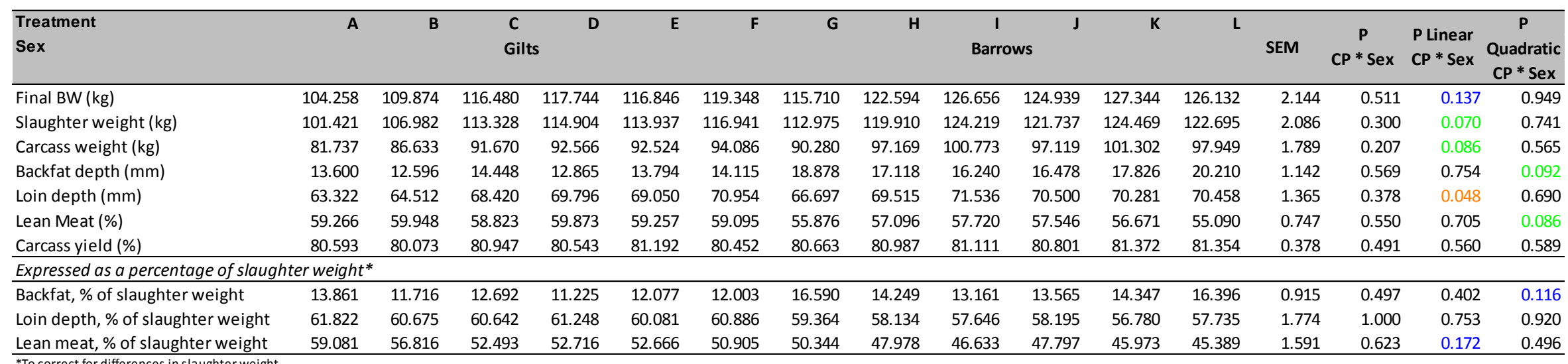


Interactions

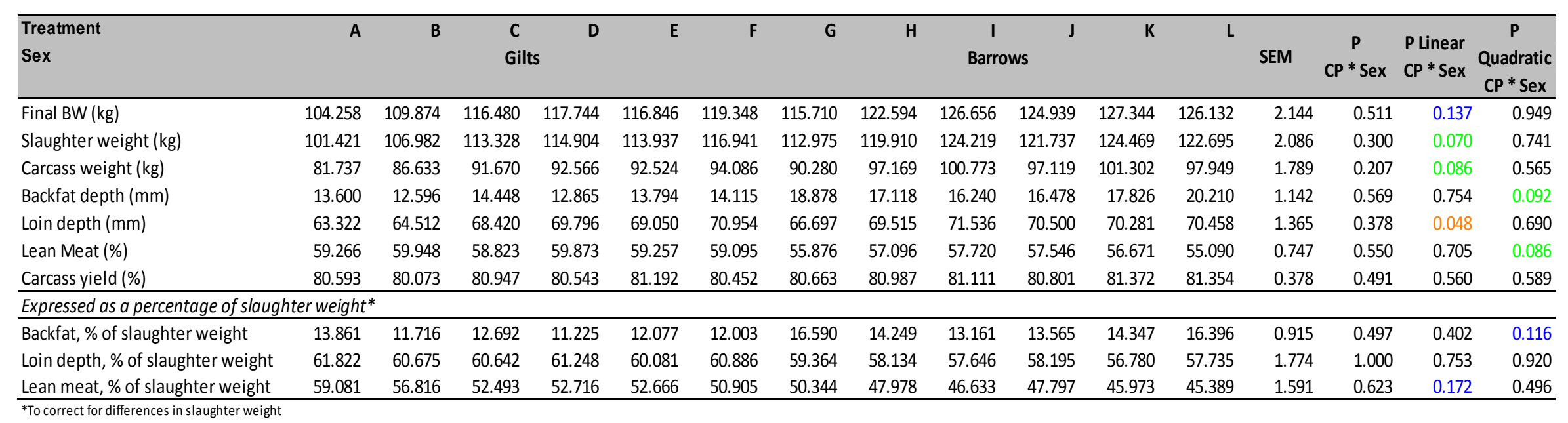






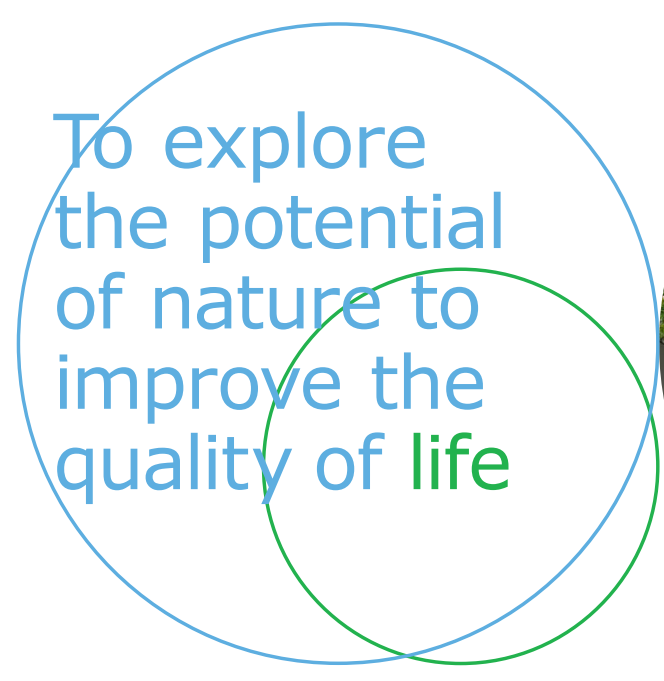

Wageningen Livestock Research P.O. Box 338

$6700 \mathrm{AH}$ Wageningen

The Netherlands

$T+31(0) 317483953$

E info.livestockresearch@wur.nl www.wur.nl/livestock-research

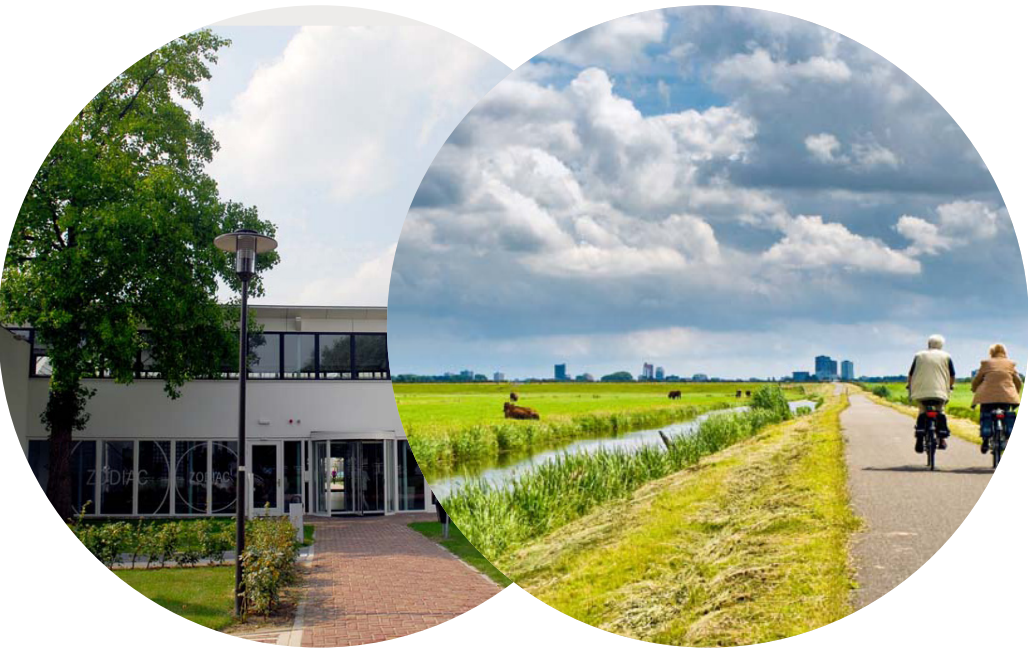

Wageningen Livestock Research creates science based solutions for a sustainable and profitable livestock sector. Together with our clients, we integrate scientific knowledge and practical experience to develop livestock concepts for future generations.

Wageningen Livestock Research is part of Wageningen University \& Research. Together we work on the mission: 'To explore the potential of nature to improve the quality of life'. A staff of 6,500 and 10,000 students from over 100 countries are working worldwide in the domain of healthy food and living environment for governments and the business community-at-large. The strength of Wageningen University \& Research lies in its ability to join the forces of specialised research institutes and the university. It also lies in the combined efforts of the various fields of natural and social sciences. This union of expertise leads to scientific breakthroughs that can quickly be put into practice and be incorporated into education. This is the Wageningen Approach. 